\title{
An overview of the cycloaddition chemistry of fulvenes and emerging applications
}

\author{
Ellen Swan ${ }^{\ddagger 1}$, Kirsten Platts ${ }^{\ddagger 1}$ and Anton Blencowe ${ }^{\star 1,2}$
}

\author{
Review \\ Address: \\ ${ }^{1}$ School of Pharmacy and Medical Sciences, The University of South \\ Australia, Adelaide, South Australia 5000, Australia and ${ }^{2}$ Future \\ Industries Institute, The University of South Australia, Mawson Lakes, \\ South Australia 5095, Australia \\ Email: \\ Anton Blencowe* - anton.blencowe@unisa.edu.au \\ * Corresponding author $\ddagger$ Equal contributors \\ Keywords: \\ cycloaddition; fulvene; polycyclic scaffolds
}

Beilstein J. Org. Chem. 2019, 15, 2113-2132.

doi:10.3762/bjoc. 15.209

Received: 03 June 2019

Accepted: 21 August 2019

Published: 06 September 2019

Associate Editor: B. Stoltz

(C) 2019 Swan et al.; licensee Beilstein-Institut. License and terms: see end of document.

\begin{abstract}
The unusual electronic properties and unique reactivity of fulvenes have interested researchers for over a century. The propensity to form dipolar structures at relatively low temperatures and to participate as various components in cycloaddition reactions, often highly selectively, makes them ideal for the synthesis of complex polycyclic carbon scaffolds. As a result, fulvene cycloaddition chemistry has been employed extensively for the synthesis of natural products. More recently, fulvene cycloaddition chemistry has also found application to other areas including materials chemistry and dynamic combinatorial chemistry. This highlight article discusses the unusual properties of fulvenes and their varied cycloaddition chemistry, focussing on applications in organic and natural synthesis, dynamic combinatorial chemistry and materials chemistry, including dynamers, hydrogels and charge transfer complexes. Tables providing comprehensive directories of fulvene cycloaddition chemistry are provided, including fulvene intramolecular and intermolecular cycloadditions complete with reactant partners and their resulting cyclic adducts, which provide a useful reference source for synthetic chemists working with fulvenes and complex polycyclic scaffolds.
\end{abstract}

\section{Introduction}

Fulvenes are an interesting organic class of cross-conjugated, cyclic molecules first discovered by Thiele in 1900, with the preparation of pentafulvenes by condensation of aldehydes and ketones with cyclopentadiene [1-8]. Most commonly encountered are pentafulvenes, although tria- [4,9-12], hepta- [9,13-28] and nonafulvenes have also been studied (Figure 1). Historically, fulvenes were of great interest as a result of their unique reactivity resulting from their exocyclic double bond [9,29-32], and more recently, as intermediates in the synthesis of more complex polycyclic scaffolds via cycloaddition reactions. While this highlight article will focus primarily on the cycloaddition chemistry of fulvenes and its applications, a brief introduction to the properties and reactivity of fulvenes, important to understanding their participation in cycloaddition reactions, is 
initially provided. For a more general background on the chemistry of pentafulvenes, in particular their fundamental properties, synthetic transformations, organometallic chemistry and metal-catalysed reactions, an excellent review was recently published by Radhakrishnan and co-workers [33]. This highlight article is intended to give the reader an overview of the varied and exceptional cycloaddition chemistry of fulvenes, and applications that can arise from this.

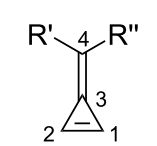

triafulvene<smiles>[R]C([R])=C1C=CC=CC=C1</smiles>

heptafulvene

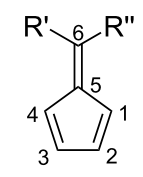

pentafulvene

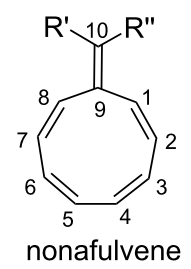

Figure 1: General structure of fulvenes, named according to the number of carbon atoms in their ring. Whilst fulvenes have been numbered using several different systems, Chemical Abstracts nomenclature is used throughout this article [34].

The replacement of skeletal carbon atoms with heteroatoms affords heterofulvenes. Some common heterofulvenes include oxa-, aza-, sila-, phospha- and thiafulvene derivatives (Figure 2). The introduction of heteroatoms results in differing reactivities, which can be further influenced by substituents, making them useful building blocks for the synthesis of polycyclic compounds [32,35-39]. This is another rich and interesting area of chemistry, although further discussion of heterofulvenes is outside the scope of the current overview and the reader is directed to a very good review by Kawase and Kurata [32].

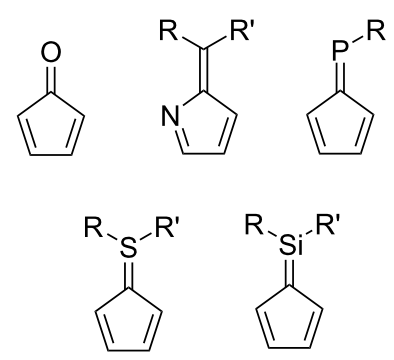

Figure 2: Generic structures of commonly referenced heteropentafulvenes, named according to the heteroatom substitution: oxafulvene, azafulvene, phosphafulvene, thiafulvene and silafulvene.

\section{Review}

\section{Fulvene properties and reactivity}

The exocyclic double bond of fulvenes is easily polarised, giving rise to dipolar resonance structures (Scheme 1) $[1-3,5,9,31,32,40-48]$.

Generally, fulvenes are thermally unstable, sensitive to oxygen [7,14,49-55], and photosensitive [42,54,56,57]. Fulvenes react with both nucleophiles and electrophiles (according to frontier orbital theory) $[1,2,58]$, and are prone to acid- and cation-catalysed polymerisations [7,14,44,55,58-60]. In addition, fulvenes readily participate in cycloaddition reactions, which will be discussed in more detail in successive sections. The high reactivity of fulvenes is mostly centred about the polarisable exocyclic double bond [1-3,5,6,9,14,32,40,42-45,48,56,61-67]. By considering the dipolar resonance structures of fulvenes, whereby either cationic (1a and $\mathbf{2 a}$ ) or anionic (1b and $\mathbf{2 b}$ ) charged centres are formed at the cyclic carbon of the exocyclic double bond, their aromatic character and reactivity becomes more predictable [1,2,5,9,30,42-45,48,52-54,56,62-64,67-69] (Scheme 1).

a)

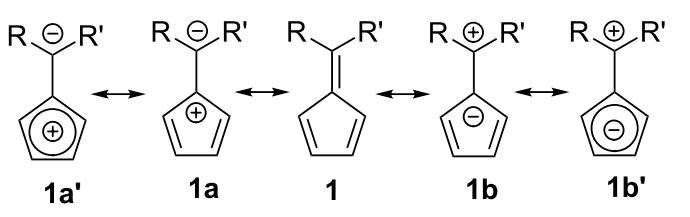

b)

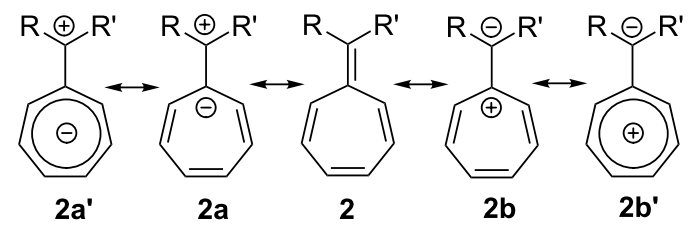

Scheme 1: Resonance structures of (a) pentafulvene and (b) heptafulvene showing neutral (1 and $\mathbf{2}$ ), dipolar (1a, $\mathbf{1 b}, \mathbf{2 a}$ and $\mathbf{2 b}$ ), aromatic (16' and 2b') and anti-aromatic (1a' and 2a') forms.

Whilst delocalisation of electrons from the dipolar form leads to a lower energy aromatic structure for pentafulvene (1)') and nonafulvene derivatives $[1,42,45,64,67]$, similar dipolar forms for triafulvene and heptafulvene (2a') derivatives would lead to higher energy anti-aromatic transition states $[1,2,9,15]$. Additionally, upon conversion to the dipole forms (Scheme 1), the fulvene loses total planarity through the exocyclic carbon $\mathrm{sp}^{2} \rightarrow \mathrm{sp}^{3}$ hybridisation, allowing some loss of energy (and gain in stability) through bond rotation $[30,61,62,70]$.

Furthermore, the nature of the substituents on the exocyclic carbon influences the fulvene reactivity and stability (Scheme 2) [30,42,48,52-54,64,67,69,71]. An ab initio study by Krygowski 
et al. [15] reported that pentafulvene derivatives (not aromatic in the neutral form), when substituted with electron-withdrawing groups (EWG) (e.g., CN) or electron-donating groups (EDG) (e.g., O, N) on the exocyclic C6-position, exhibited antiaromatic and aromatic ring currents, respectively [5,29,64,67,72]. Hence, EDG stabilise pentafulvenes (3b'), whereas EWG stabilise heptafulvenes (6b') $[9,67]$. In many cases, the reactions of fulvenes are peri- [17,22,28,73-80], enantio- [81-87], diastereo- [17,21,26,28,81,88-92], and regioselective $[17,28,74-76,81,82,93,94]$, and result from the electronic nature of the fulvene, the reactant partner, as well as steric arguments. a)<smiles>[R]C(CC)=C1C=CC=C1</smiles>

3

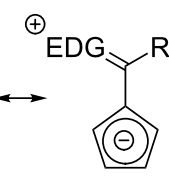

3b'

b)

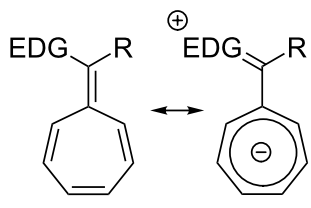

5
$5 a^{\prime}$

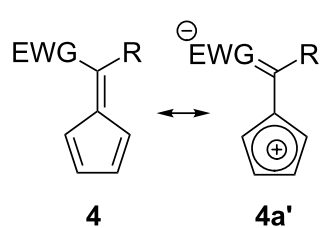

$4 a^{\prime}$

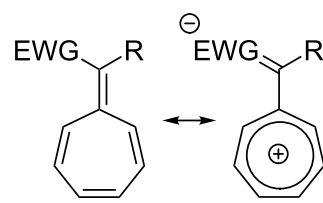

6 6b'
Scheme 2: Resonance structures of (a) pentafulvenes and (b) heptafulvenes showing the influence of EDG and EWG on the aromatic (3b' and $\left.\mathbf{6} \mathbf{b}^{\prime}\right)$ and anti-aromatic (4a' and $5 \mathbf{a}^{\prime}$ ) ring currents.

In addition, substituents that are distant, but conjugated to the fulvene group, influence the aromaticity of the molecule $[69,71]$, ultimately allowing modification of the molecule's reactivity for a given reaction. This was demonstrated in a study by Gugelchuck et al. [71], where the reaction rate of various $p$-substituted 6-phenylpentafulvenes with maleimides was investigated. Substituents of an electron-donating nature (e.g., H, halogens) generally increased the reaction rate through stabilisation of the Diels-Alder transition state, whilst those which were electron-withdrawing (e.g., $\mathrm{NO}_{2}, \mathrm{CN}, \mathrm{NMeAc}$ ) decreased the reaction rate. Interestingly, strong EDG (e.g., $\mathrm{OMe}, \mathrm{NMe}_{2}$ ) exhibited a slower reaction rate than predicted, but this is likely due to the increased stabilisation of the reactant, rather than the transition state [71].

Fulvenes can be quite sensitive to oxygen, which has been documented for pentafulvenes and heptafulvenes $[16,47,54,55,95]$. Pentafulvenes have been reported to react with both ground (triplet) $[51,52,55]$ and excited (singlet) state oxygen $[7,49,50,53]$ resulting in the formation of several different products, although predominantly enol lactones [47,50-52]
(Scheme 3). Highly reactive intermediates formed during these reactions (Scheme 3 ) have only been observed spectroscopically at low temperatures $\left(-55^{\circ} \mathrm{C}\right)$ [52].

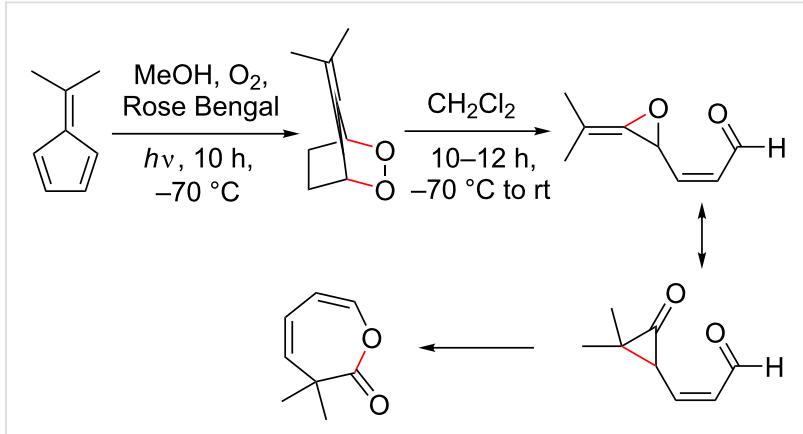

Scheme 3: Reaction of 6,6-dimethylpentafulvene with singlet state oxygen to form an enol lactone via the multistep rearrangement proposed by Harada et al. (supporting information was not provided) [51].

Heptafulvenes also undergo reactions with singlet state oxygen to form similar peroxide, epoxide or epidioxide [16] derivatives, which can be isolated at room temperature (Scheme 4).

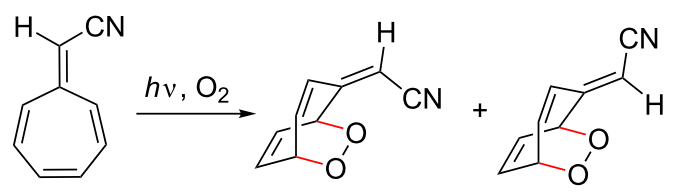

Scheme 4: Photosensitized oxygenation of 8-cyanoheptafulvene with singlet state oxygen to afford 1,4-epidioxide isomers [16].

An interesting physical characteristic of pentafulvene derivatives is their bright colour, which results from their cross conjugation, and varies with substitution, particularly at the exocyclic C6 position $[1,2,6,42,71]$. Considering molecular orbital theory, pentafulvenes have a high-energy highest occupied molecular orbital (HOMO) and low-energy lowest unoccupied molecular orbital (LUMO) [1,2,6,42] (HOMO-LUMO) energy gap that is small enough to allow the absorption of long wavelength UV radiation, thus the molecule appears yellow or red [2]. The size of this energy gap can be altered by EWG (-M effect) and EDG $(+\mathrm{M}$ effect) substituents (Figure 3$)$, through decreasing or increasing the LUMO energy, respectively [1-3,6,7,42,62,67,71]. In some cases, this can result in a bathochromic shift $[2,42]$. Consideration of frontier molecular orbital theory allows the electronic nature and general reactivity patterns of fulvenes to be interpreted.

\section{Fulvene cycloadditions}

The multiple cycloaddition pathways observed for fulvenes provides access to a diverse and unique range of fused ring and 


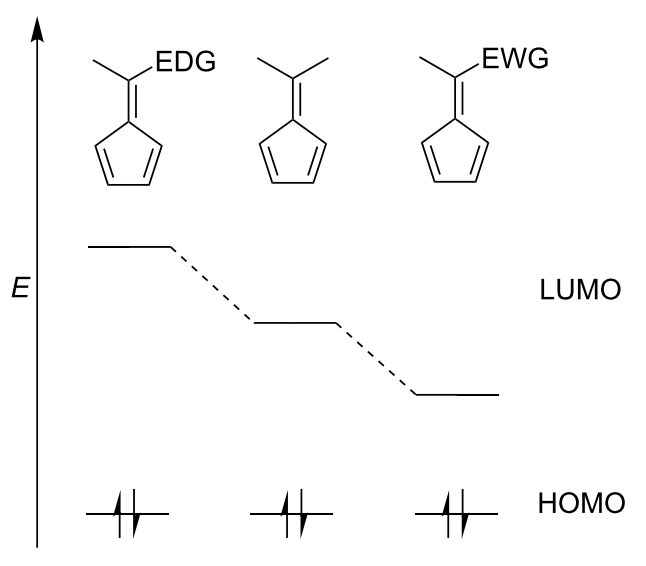

Figure 3: A representation of HOMO-LUMO orbitals of pentafulvene and the influence of EWG and EDG substituents.

polycyclic scaffolds. In the subsequent sections, the cycloaddition chemistry of fulvenes will be discussed in terms of their dimerization, and intra- and intermolecular reactions. Whereas the high reactivity and poor stability of triafulvenes have limited studies into their cycloaddition chemistry [1,2,4,10-12], the relative stability of pentafulvenes has allowed extensive research into their participation as $2 \pi, 4 \pi$ and $6 \pi$ components. Additionally, pentafulvenes participating as $8 \pi, 10 \pi$ and $12 \pi$ components via an extended conjugated chain at the exocyclic C6 position have also been reported. For higher-order heptaand nonafulvenes, the extended conjugated system also allows them to act as $8 \pi$ components, as well as $2-6 \pi$ components.

Pentafulvenes can react as $2 \pi$ components with moderately electron-deficient dienes and $4 \pi$ components in reactions with dienophiles (Scheme 5a), whereas pentafulvenes substituted with EDG (e.g., $\mathrm{NMe}_{2}$ ) at the exocyclic $\mathrm{C} 6$ position possess an increased electron density about the fulvene $\pi$-system, increasing the stability and hence nucleophilicity of the fulvene $[29,73,96-104]$. This allows the fulvene to function as a $6 \pi$ component in reactions with electron-deficient dienes (Scheme 5b) and fulvenes acting as dipolarophiles have been reported for enantioselective [6+3] and [3+2] cycloadditions $[83,84,105]$. In general, reactions with electron-rich alkenes will take place preferentially at the exocyclic C6 position while other less electron-rich species interact most strongly with the fulvene HOMO resulting in only [4 +2$]$ cycloadditions $[101,103]$.

In some cases, cycloaddition reactions involving fulvenes may be difficult to characterise due to the high reactivity of the fulvene group, and the ability to act as multiple cycloaddition components, leading to multiple mechanistic pathways. For example, the cycloaddition of tropone and fulvenes was initially

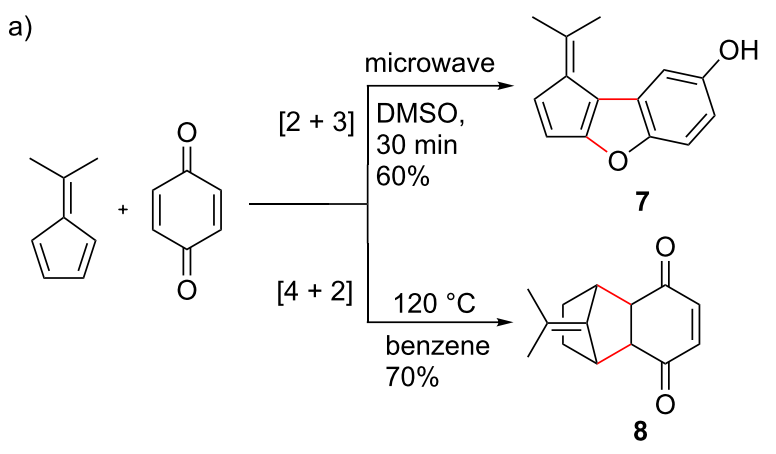

b)

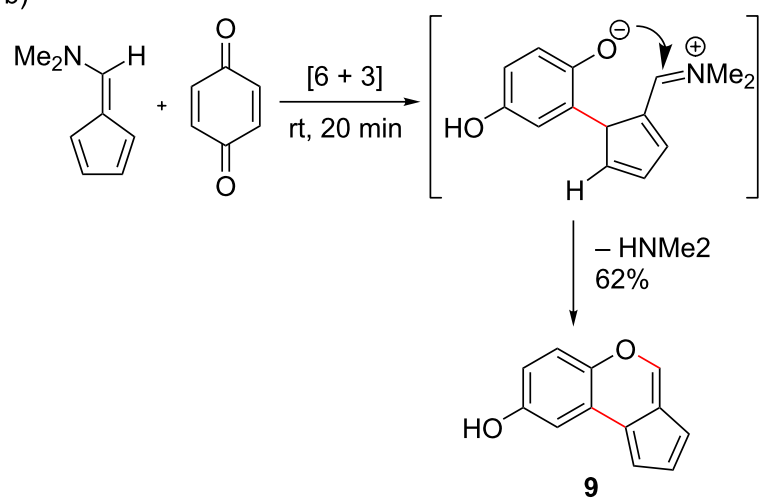

Scheme 5: Reactions of (a) 6,6-dimethylpentafulvene participating as $2 \pi$ and $4 \pi$ components in cycloadditions with $p$-benzoquinone to afford [2 + 3] (7) and [4 + 2] (8) cycloadducts, and (b) 6-(dimethylamino)pentafulvene participating as a $6 \pi$ component in a [6 +3] cycloaddition with $p$-benzoquinone to afford cycloadduct 9 [32].

proposed by Houk to proceed via a peri-, regio- and stereoselective $[6+4]$ cycloaddition of tropone $[4 \pi]$ to fulvene [6 $]$ [106]. However, an alternate mechanism was proposed by PaddonRow and Warraner [74], whereby an initial [6 + 4] cycloaddition of tropone $[6 \pi]$ to fulvene $[4 \pi]$ and subsequent Cope rearrangement produced the formal $[6+4]$ adduct. More recently, $\mathrm{Yu}$ et al. demonstrated through computations that the initial cycloaddition proceeds through an ambimodal $[6+4] /[4+6]$ transition state leading to both of the proposed [6+4] adducts, which can interconvert through a Cope rearrangement (Scheme 6) [107].

\section{Dimerisation cycloadditions}

Generally, dimerization of fulvenes is an undesired process that may occur upon storage, or compete during reactions with other substrates. As a result of their structure and reactivity, triafulvene [4] and pentafulvene [31,59,66,108-118] derivatives are susceptible to dimerization. The high ring strain of triafulvenes makes them particularly thermally unstable, with dimerization occurring at temperatures higher than $-75^{\circ} \mathrm{C}$ [4]. The dimerization of triafulvene derivatives is hypothesised to occur via a $[4+4]$ cycloaddition pathway (Scheme 7) [4]. Whilst the 


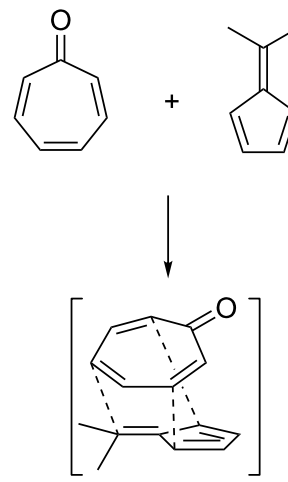

(ambimodal TS)

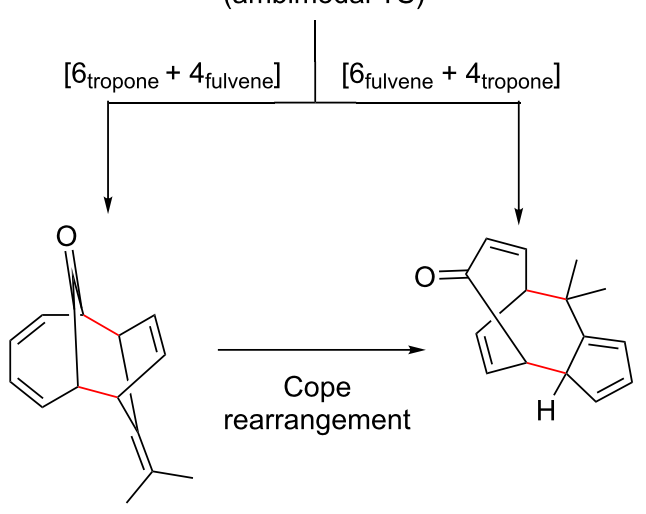

Scheme 6: Proposed mechanism for the $[6+4]$ cycloaddition of tropone with dimethylfulvene via an ambimodal $[6+4] /[4+6]$ transition state.

dimers are also unstable (rapid decomposition when neat), they can be observed spectroscopically at $-20^{\circ} \mathrm{C}$ [4].

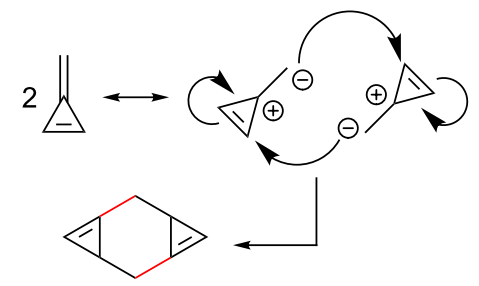

Scheme 7: Triafulvene dimerization through the proposed 'head-to-tail' mechanism. The dipolar transition state is shown as the intermediate [4].

There have been numerous reports of pentafulvenes undergoing dimerization via Diels-Alder cycloadditions (DACs) (Scheme 8 ) at room temperature $[6,66,108,109,114,115,117,119]$. In some cases, the resulting dimers can undergo subsequent cycloadditions to form trimers via [6 + 4] cycloadditions $[109,110]$ or polymeric products $[6,71,109,118]$, which are often not desired due to the difficulties associated with purification.
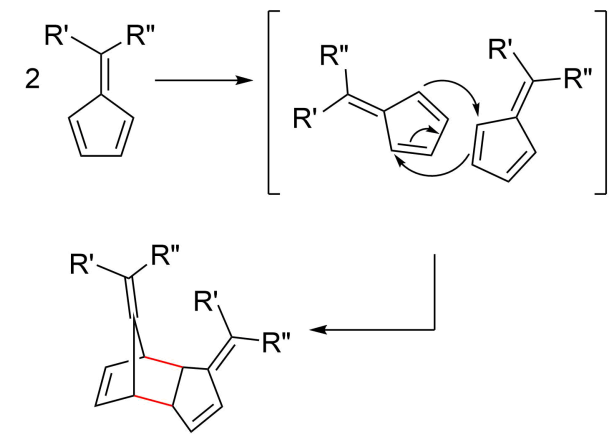

Scheme 8: Dimerization of pentafulvenes via a Diels-Alder cycloaddition pathway whereby one fulvene acts as a diene and the second fulvene acts as a dienophile.

Additionally, a formal $[6+4]$ dimerization was reported by Mömming et al. utilising frustrated Lewis pair chemistry (Scheme 9), however, the mechanism of this process requires further clarification [116].

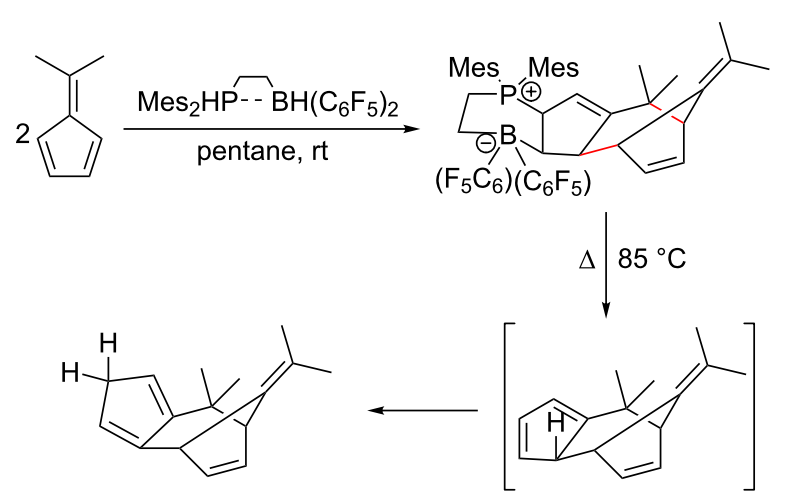

Scheme 9: Dimerization of pentafulvenes via frustrated Lewis pair chemistry as reported by Mömming et al. [116].

The rate of dimerization is partly dependent on the fulvene reactivity, which is strongly influenced by its substituents (as discussed previously). For instance, stabilised tria- and heptafulvenes with EWG and penta- and nonafulvenes with EDGs dimerize more slowly $[42,64,65,67,71]$. The rate of dimerization is also affected by the hydrophilicity and solubility of the fulvene, with groups that lower the hydrophobic character appearing to decrease the rate. For example, the anti-aromatic resonance structure of pentafulvene (1a') (Scheme 1), which is highly reactive, is prone to dimerization and polymerisation $[59,111]$. If the reaction is conducted under aqueous conditions, the probability of dimerization has been reported to increase further due to hydrophobic packing of the fulvene molecules $[120,121]$ 


\section{Intramolecular cycloadditions}

Whilst not as widely reported as intermolecular cycloaddition reactions, there are some interesting reports regarding the intramolecular cycloaddition of fulvenes, summarised in Table 1 .

For the intramolecular cycloadditions of pentafulvenes, the fulvene has been reported to react as both diene and dienophile depending on the reacting partner in the structure $[91,119,127]$. For example, pentafulvenes tethered to various dienes have been employed as precursors to various polycyclic ring systems, including kigelinol, neoamphilectane and kempane skeletons, which can be formed in a stereospecific manner depending upon the tether length of the extended pentafulvene chain, and the role of the fulvene in the reaction (diene or dienophile) [127]. In these examples, kigelinol and neoamphilectane are of great interest in biomimetic and natural product chemistry, as they exhibit antitrypanosomal [128,129] and antimalarial [130] activity, respectively. Soldier nasute termites use secretion of tetracyclic kempane skeletons as a defence mechanism [131], so their complete synthesis would invite further characterisation of the termite species. In a comprehensive study by Hong et al., precursor skeletons to kigelinol and kempane (Scheme 10)

Table 1: Structures and cycloaddition notation of fulvene intramolecular cycloadditions.

Fulvene precursor<smiles>C=C[C@@H](OCc1ccccc1)C(C)(C)CC1=CC(OCC)=C(C(=O)OCC)C1=COc1ccccc1</smiles><smiles>[R]OC([R])=CCCOc1ccc2ccccc2c1C=C1C=CC=C1</smiles><smiles>[R]OC(=O)C=CCOc1c([R2])cc([R1])cc1C=C1C=CC=C1</smiles><smiles>C=CC=CC(C)(C)C(=O)OC=C1C=CC=C1</smiles><smiles>O=CCCCCC=C1C=CC=C1</smiles><smiles>[R]C(=C1C=CC=C1)C([R])([R])CCC([R])C=O</smiles>

Cycloaddition product

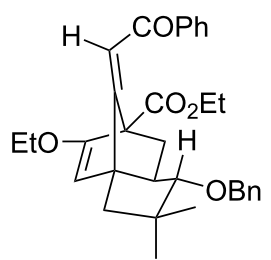

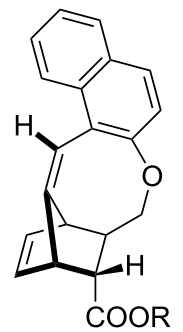

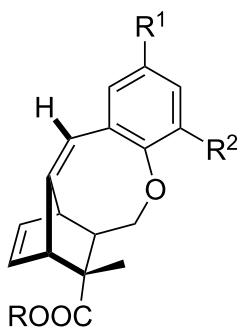<smiles>CC1(C)C(=O)OC2CC3(C=CC=C3)CC=CC21</smiles><smiles>C1=CC2=CC3CCCC3C2C1</smiles><smiles></smiles>

References 
Table 1: Structures and cycloaddition notation of fulvene intramolecular cycloadditions. (continued)<smiles>C=CC=CC(C)(C)C(=O)OC=C1C=CC=C1</smiles><smiles>CC1(C)C(=O)OC2C3=C(C=CC3)CC=CC21</smiles><smiles>CCN(/C=C/C=C\CCCC(C)=C1C=CC=C1)CC</smiles><smiles>[R]C12CCC[C@H]1C=CC=C1C=CC=C1C2</smiles><smiles>CC1=C2C=CC3CC=CCC3CCCC2C=C1</smiles><smiles>[X]C(C(=O)OCC=CC(=O)OCC)=C1C=CC=CC=C1</smiles>
$\mathrm{X}=\mathrm{H}$ or $\mathrm{CN}$<smiles>[X]C12C(=O)OC[C@H]1[C@@H](OCC)[C@]1([R])C=CC=CC=C21</smiles><smiles>CCOC(=O)/C=C/COC(=O)C(C#N)=C1C=CC=CC=C1</smiles><smiles>CCOC(=O)[C@H]1C2C=CC=CC2C2(C)CCCC[C@H]12</smiles>

polycyclic ring systems were synthesised using DACs with extended-chain pentafulvenes, in 5 and 9 steps, respectively [127]. Progress has also been made towards synthesis of a neoamphilectane skeleton, but requires further optimisation to obtain the desired products.

A versatile organocatalytic, enantioselective intramolecular cycloaddition reaction was reported by Hayashi et al. for the synthesis of various tricyclopentanoids from pentafulvenes with $\delta$-formyl groups tethered to the exocyclic C6 position via structurally distinct spacers [85]. The intramolecular [6+2] cycloaddition was found to occur between the fulvene and an enamine generated through the reaction of the formyl group with the organocatalyst, diphenylprolinol silyl ether. Variation of the spacer structure provided access to a range of triquinane derivatives (Scheme 11), an important precursor in biomimetic and natural products [85].

Heptafulvenes have also been documented to react in intramolecular cycloaddition reactions [22,25,27]. Liu et al. synthesised an unsymmetric heptafulvene molecule containing a pentafulvene moiety (Scheme 12), which consequently underwent a $[8+6]$ cycloaddition to diastereoselectively form a complex tetracycle [22,27].

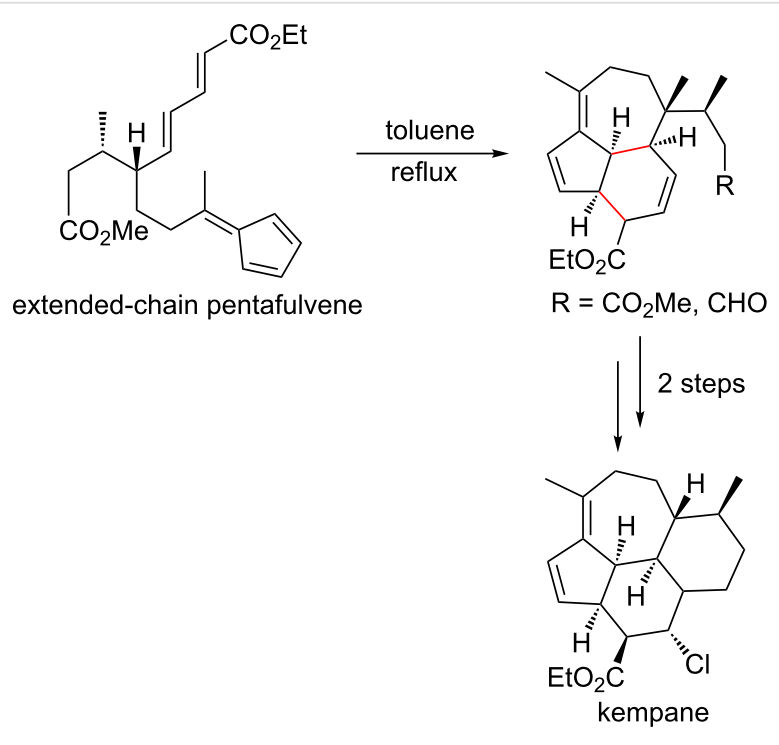

Scheme 10: Simplified reaction scheme for the formation of kempane from an extended-chain pentafulvene [127].

\section{Intermolecular cycloadditions}

Intermolecular cycloadditions of fulvenes have been studied using a wide range of different reactant partners to provide a varied array of different and often complex polycyclic scaf- 


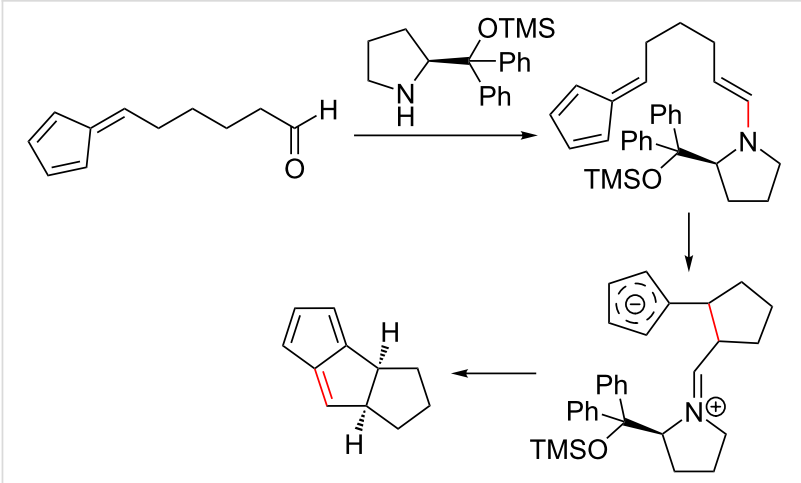

Scheme 11: The enantioselective ( $>99 \%$ ee), asymmetric, catalytic, intramolecular $[6+2]$ cycloaddition of fulvenes as reported by Hayashi et al. [85].

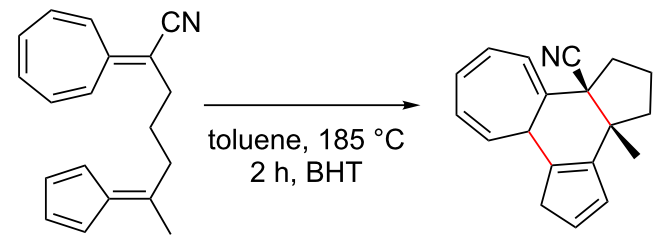

Scheme 12: Intramolecular [8 + 6] cycloaddition of the heptafulvenepentafulvene derivative [22,27].

folds. The choice of reactant partner often determines the type of cycloaddition and how the fulvene will behave, and have been summarised in Table 2.
Albeit one of the less documented fulvene classes (likely due to their extreme sensitivity $[4,11,12])$, triafulvenes have been reported to participate in both $[2+2][10,11]$ and $[4+2][12]$ cycloadditions. For the former, the reaction of an aminodiene with a triafulvene initially resulted in the formation of a $[2+2]$ cycloadduct, and an energetically strained 4-membered ring inevitably undergoes subsequent ring-opening (Scheme 13a) [10]. During the $[4+2]$ cycloaddition, the triafulvene could only be generated in situ from methyl(2-methylenecyclopropyl)(phenyl)sulfonium tetrafluoroborate (Scheme 13b).

As pentafulvenes are the most commonly studied fulvenes, it follows that there is a great deal of literature surrounding their reactivity in cycloaddition reactions. Due to conjugation, they can function as $2 \pi, 4 \pi, 6 \pi$ or $10 \pi$ components (Table 2 ). This functionality is dependent both on the other reactant partner, and the electronic effects of the fulvene substituents [96$99,153,156]$. As an example, in [4 +2] cycloadditions, fulvenes will participate as $4 \pi$ components (diene), provided they are more electron-rich than the reactant partner [71,163,183].

Pentafulvenes show dual capabilities in DACs, with documented examples of them functioning as both dienes and dienophiles $[55,114,150,151,154,159,174-176,227-229]$. The exact nature of the fulvene moiety is dependent mostly on its substituents (e.g., EWG or EDG) relative to the other reactants $[6,42,45,67,103,153,230]$. Maleimides (including maleic anhydride) [55,71,92,96,150,176,177,179-184,186,192,229,231],

Table 2: Fulvene intermolecular cycloadditions with various reactant partners.

\begin{tabular}{|c|c|c|c|c|}
\hline Fulvene & $\begin{array}{l}\text { Fulvene } \\
\text { component }\end{array}$ & Cycloaddition & Reactant partner & ref \\
\hline \multirow{4}{*}{ triafulvene $_{\text {R' }}^{\mathrm{R}^{\prime}}$} & \multirow[t]{4}{*}{$2 \pi$} & \multirow{2}{*}[2+2]{} & enamines & {$[10]$} \\
\hline & & & cyclic amines & {$[11]$} \\
\hline & & {$[4+2]$} & cyclopentadienes & {$[1,12]$} \\
\hline & & & & \\
\hline \multirow{14}{*}{ pentafulvene } & \multirow[t]{14}{*}{$2 \pi$} & {$[1+2]$} & carbenes & {$[31,86,88]$} \\
\hline & & {$[2+2]$} & ketenes & [132-134] \\
\hline & & & alkynes & {$[135-137]$} \\
\hline & & & 2,4,6-triphenylpyrylium-3-olate & {$[138]$} \\
\hline & & & dichloroketenes & {$[139,140]$} \\
\hline & & {$[3+2]$} & nitrones & {$[65,141,142]$} \\
\hline & & & nitrile oxides & {$[143,144]$} \\
\hline & & & 3-oxidopyrylium betaine & {$[75,145]$} \\
\hline & & & acylnitrones & {$[146]$} \\
\hline & & & thiocumulenes & {$[79]$} \\
\hline & & & Lewis acid mediated & {$[147]$} \\
\hline & & & carbonyl ylides & {$[105]$} \\
\hline & & & 3-methyl-2,4-dipheny1-1,3-oxazolium-5-olate & [148] \\
\hline & & & 1,3-diphenylnitrilimine & [149] \\
\hline
\end{tabular}


Table 2: Fulvene intermolecular cycloadditions with various reactant partners. (continued)

\begin{tabular}{|c|c|c|c|}
\hline & \multirow[t]{23}{*}[4+2]{} & cyclopentadiene & {$[17,109,150,151]$} \\
\hline & & fulvenes & {$[17,24,137]$} \\
\hline & & tetrazines & {$[48]$} \\
\hline & & azirines & {$[57]$} \\
\hline & & halogenated dienes & [152] \\
\hline & & o-xylylenes & [153] \\
\hline & & dienes & {$[114,117,150,154,155]$} \\
\hline & & o-benzoquinones & {$[89,156-165]$} \\
\hline & & o-thioquinones & [166] \\
\hline & & 2,4,6-triphenylpyrylium-3-olate & [138] \\
\hline & & isobenzofurans & [77] \\
\hline & & diketones & [167] \\
\hline & & cyclopentadienones & [151] \\
\hline & & tetracyclic systems & [168] \\
\hline & & quinone methides & {$[87,169]$} \\
\hline & & coumalic esters & [170] \\
\hline & & tropone & {$[107]$} \\
\hline & & thiocarbonyl ylide & [171] \\
\hline & & Lewis acid catalysed & [172] \\
\hline & & mesoionic dithiolones & {$[76]$} \\
\hline & & 1,3-oxazolium-5-olates & [173] \\
\hline & & benzonitrile oxide & [73] \\
\hline & & alkynes & {$[174]$} \\
\hline & \multirow[t]{4}{*}[8+2]{} & 3-ethoxycarbonyl- $2 \mathrm{H}$-cyclohepta[b]furans & {$[18,19]$} \\
\hline & & fulvenes & {$[21,24,28]$} \\
\hline & & 3-methoxycarbonyl-2H-cyclohepta[b]furan-2-one & [23] \\
\hline & & tropothione & [78] \\
\hline \multirow[t]{22}{*}{$4 \pi$} & \multirow[t]{15}{*}[4+2]{} & fulvenes & [24] \\
\hline & & maleimides (including maleic anhydride) & {$[55,71,92,117,150,175-184]$} \\
\hline & & $p$-benzoquinones & {$[60,117,175]$} \\
\hline & & diphenylnitrone & {$[65]$} \\
\hline & & carboranes & [72] \\
\hline & & alkynes & {$[92,117,178,183,185]$} \\
\hline & & cyclopentadienone & [151] \\
\hline & & tetracyclic systems & {$[168]$} \\
\hline & & 2,2-bis(trifluoromethyl)-1,1-dicyanoethylene & [186] \\
\hline & & alkenes & {$[117,177,187-194]$} \\
\hline & & cyclopentadiene & {$[177]$} \\
\hline & & 2-chloroacrylonitrile & [178] \\
\hline & & triazoline-3,5-diones & {$[195,196]$} \\
\hline & & benzynes & [197-199] \\
\hline & & dienamines & [200] \\
\hline & \multirow[t]{4}{*}[4+3]{} & carbenes & {$[86,88]$} \\
\hline & & maleic anhydride & {$[117]$} \\
\hline & & 2-oxyallyl cations & {$[100,201]$} \\
\hline & & 1,3-diphenylnitrilimine & [149] \\
\hline & {$[4+4]$} & o-benzoquinones & [158] \\
\hline & {$[6+4]$} & o-benzoquinones & [89] \\
\hline & & tropone & [107] \\
\hline \multirow[t]{3}{*}{$6 \pi$} & {$[6+2]$} & alkynes & {$[136,137,202]$} \\
\hline & & 4-methyl-1,2,4-triazoline-3,5-dione & [195] \\
\hline & & alkenes & [97] \\
\hline
\end{tabular}




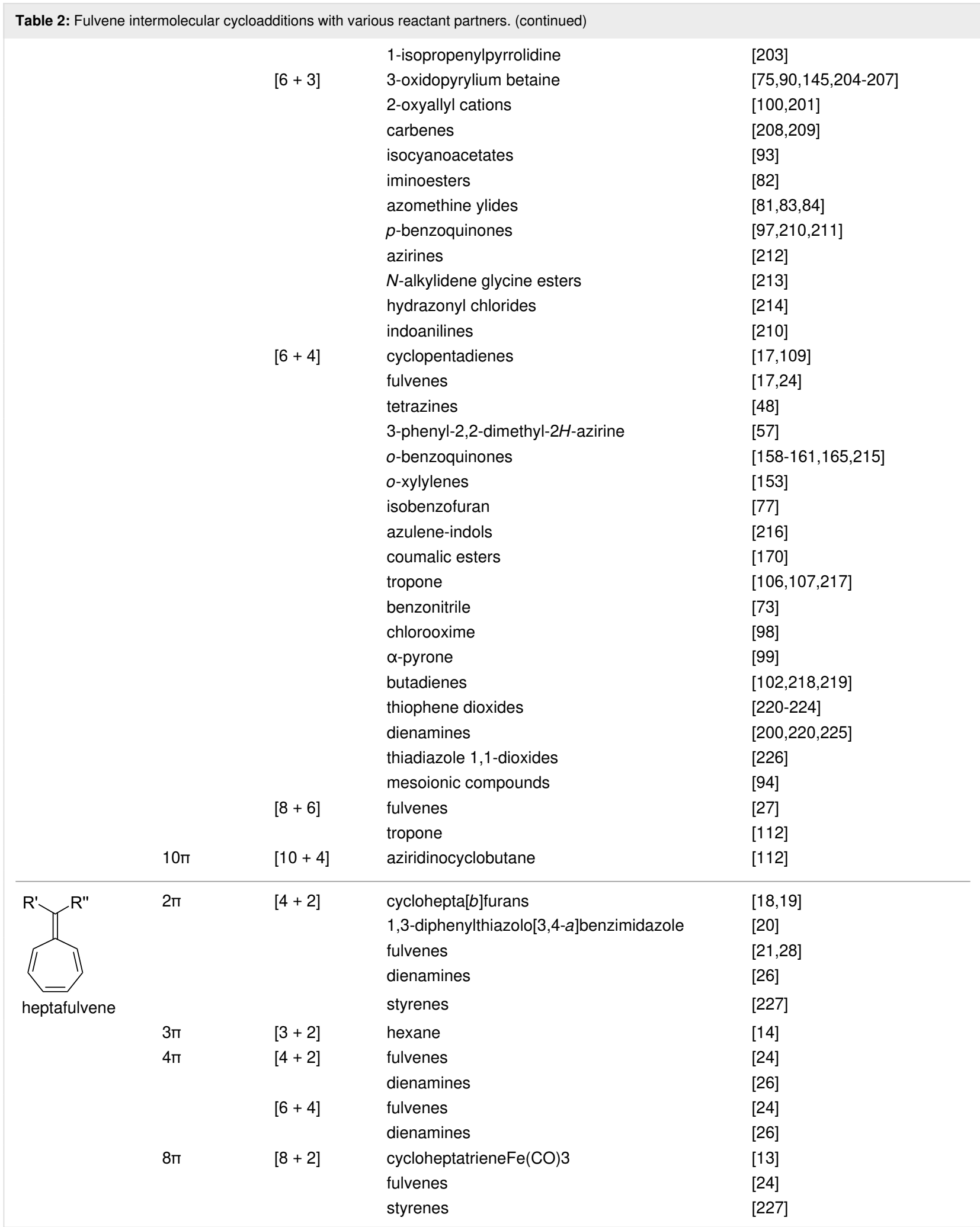

dimethyl acetylenedicarboxylate (DMAD) and $p$-benzoquinone $[60,150,159,164,175,211]$ derivatives $[174,183,200,229]$ are often used as the complementary dienophiles (Scheme 14, reac- tion pathways (i), (ii) and (iii), respectively), as well as monoand disubstituted acetylene derivatives, such as methyl propiolate [229] and dibenzoylacetylene [150]. 
a)

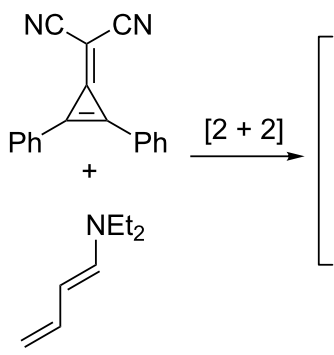

b)

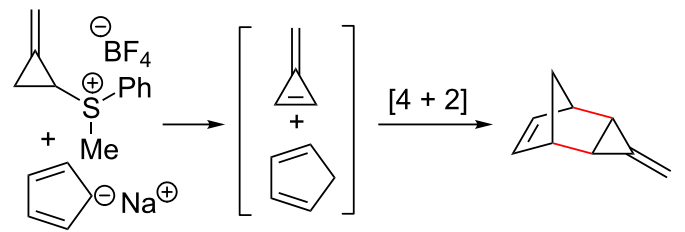

Scheme 13: Reaction scheme for (a) [2 + 2] cycloaddition of 1,2diphenylmethylenecyclopropene and 1-diethylamino-1,3-butadiene and (b) [4 + 2] cycloaddition of an in situ-generated triafulvene with cyclopentadiene.

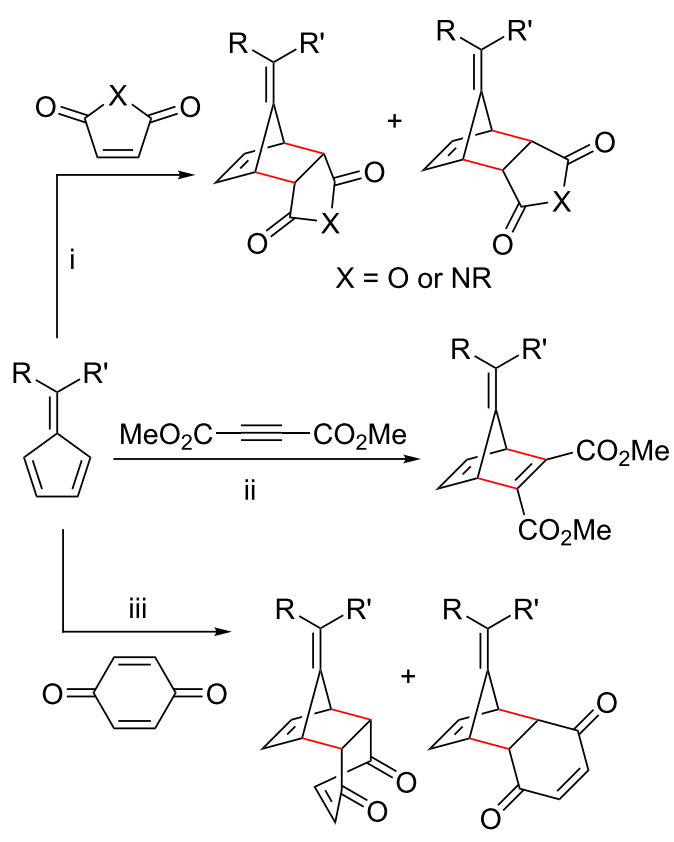

Scheme 14: Diels-Alder cycloaddition of pentafulvenes derivatives participating as dienes with (i) maleimide derivatives, (ii) dimethyl acetylenedicarboxylate (DMAD) and (iii) p-benzoquinones.
Conversely, when the fulvene has an EWG attached, it is more likely to function as a dienophile in an inverse electron-demand Diels-Alder (iEDDA) reaction $[153,154,156]$. This requires the other reactant to have strong EDGs in order to function as a diene, otherwise fulvene dimerization becomes the preferred reaction, causing the formation of complex products. Examples of dienes that have previously been used include cyclic diketones (o-benzoquinones) (Scheme 15, reaction pathways (i)) [60,89,156-158,160-165,211,215,226], o-quinone methides [87], $o$-xylylenes [125,153], polyhalogenated cyclopentadienes (Scheme 15, reaction pathways (ii)) and 2-azadienes [152,172].

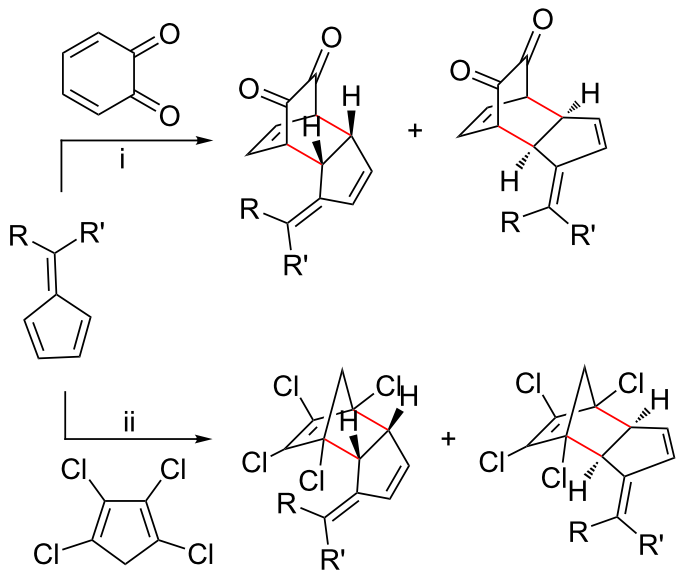

Scheme 15: Generic schemes showing pentafulvenes participating as dienophiles in Diels-Alder cycloadditions with (i) o-benzoquinones and (ii) polyhalogenated cyclopentadienes.

Regardless of the role of the fulvene moiety, the DAC is generally conducted in organic solvents at room temperature and under an inert atmosphere to prevent unwanted oxidations [24,55,94,114,150,152,159,166,172,174,176,183,186,227,229]. There are very few papers reporting the aforementioned reaction occurring in aqueous conditions [175] most likely as a result of the poor solubility of fulvene derivatives in water [175].

Although the stereochemistry of DACs can usually be predicted by the 'endo rule' $[92,176,229,232]$, there are some exceptions, particularly when sterically-demanding fulvenes, such as norbornyl-fused fulvenes [229] or adamantilydenefulvene [174] are involved. In the literature, many cycloaddition reactions have been conducted with dimethylfulvene [52,97,106,118,133,134] or diphenylfulvene $[20,103,114,133,163,180]$. In each instance, the endo stereochemistry of the cycloadduct is dominant $[91,176,180]$, indicating that the fulvene substituents in the exocyclic C6 position are too distal to impact the stereoselectivity $[76,229]$. 
There are documented cases of heptafulvenes [18-21,26,28,227] also participating in such reactions. However, Nair et al. reported that during cycloadditions of 8,8-dicyanoheptafulvene and styrene derivatives (Scheme 16), $[8+2]$ and $[4+2]$ adducts formed in approximately $1: 1$ ratio for each styrene variant tested, thus lowering the yield of the Diels-Alder adduct [227].

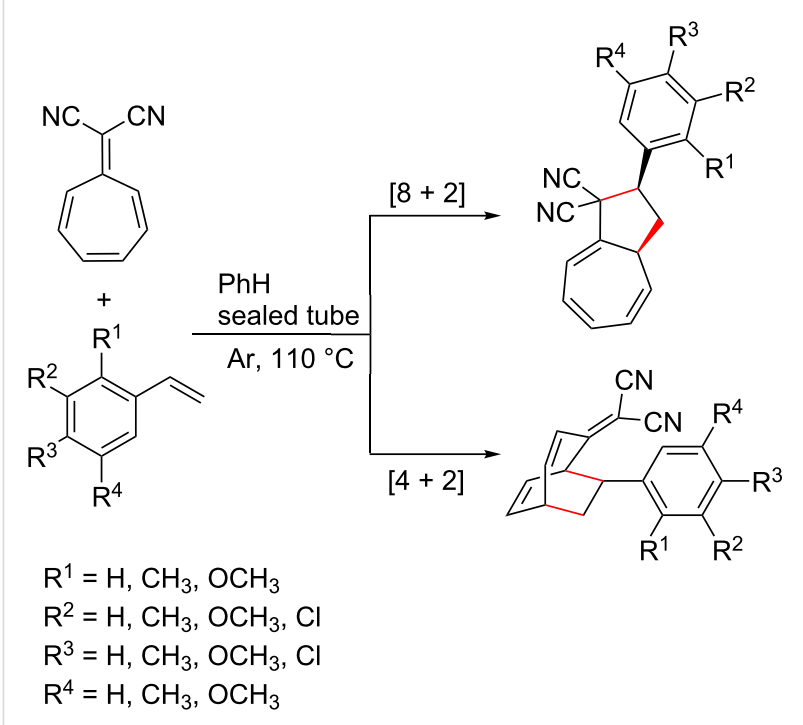

Scheme 16: Reaction of 8,8-dicyanoheptafulvene and styrene derivatives to afford [8+2] and [4+2] cycloadducts in a 1:1 ratio [227].

Of particular interest is the reaction between 6-aminofulvenes and maleic anhydride. As previously reported, a fulvene reacting with maleimides (including maleic anhydride) generally results in a $[4+2]$ cycloaddition (Scheme 14 , reaction pathway (i)) $[55,96,150,176,229]$. However, when Houk et al attempted to react a range of 6-aminofulvenes with maleic anhydride, a [6 +2] cycloaddition was observed (Scheme 17) [114]. This unusual reactivity is hypothesised to be due to an increased electron density in the 6-aminofulvene $\pi$-system [96], which would increase the nucleophilic character, and stabilise the fulvene system (see dipolar forms in Scheme 1). Similar results have been observed by other groups [32,96,124,203]

Whilst many of the documented reactions focus on chemical synthesis and characterisation rather than applications, several synthetically interesting scaffolds have been synthesised, including products which exhibit biological activity, complex ligands in coordination chemistry, and several natural product skeletons (Table 3 ).

\section{Applications of fulvene cycloadditions Organic and natural product synthesis}

A variety of organic molecules and natural products have been synthesised using fulvenes in cycloadditions (Table 3). Penta-

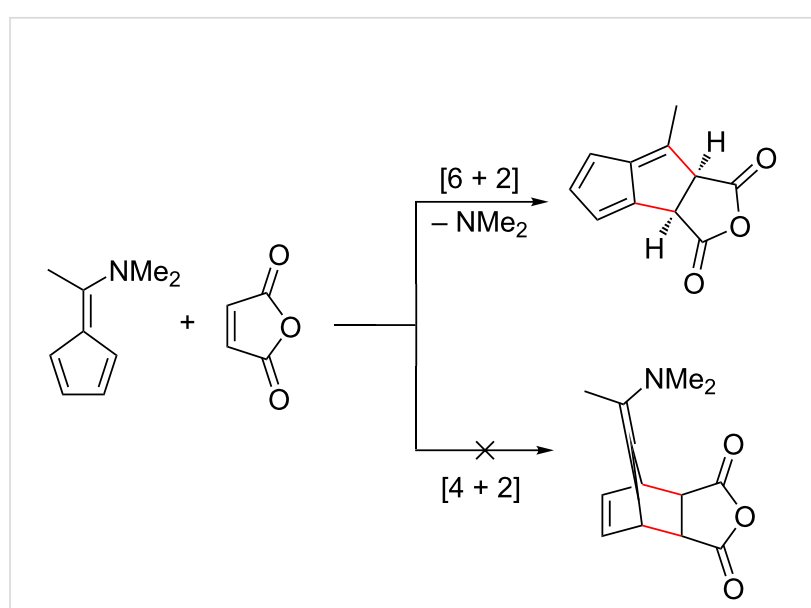

Scheme 17: Reaction of 6-aminofulvene and maleic anhydride, showing observed $[6+2]$ cycloaddition; the $[4+2]$ cycloaddition is not observed [114].

fulvenes appear to be the only fulvenes used in this approach, likely due to their relative stability compared to other members of the fulvene family, diverse cycloaddition chemistry, and easy access $[42,45,64,67]$. The synthesis of the listed organic molecules (Table 3 ) is generally successful, with high yields in almost all cases. However, some of these synthetic pathways are multistep [124], hence require optimisation for viability and large-scale production.

Similarly, pentafulvenes have been used as key reactants for the synthesis of natural products and their skeletons (Table 3 ). The complexity of these molecules requires extensive multistep pathways (ranging from 5-12 steps [127,187]), decreasing overall yields, and thus requiring further optimisation for commercial production. Narayan et al. developed a programmable enantioselective one-pot synthesis of molecules with eight stereocentres greatly improving the efficiency of natural product synthesis [83].

Each of these natural products are biologically active, hence their total synthesis will allow further characterisation of their reactivity and mechanisms of action.

\section{Dynamic combinatorial chemistry}

Dynamic combinatorial chemistry (DCC) is an emerging field with promising applications in drug discovery. DCC involves the generation of new molecules via reversible reactions of simple building blocks, referred to as a dynamic combinatorial library (DCL). As the reactions are reversible, several different structures are possible and the system exists in equilibrium. Upon the addition of an external surface (binding target), the equilibrium is altered and the product most stabilised through 
Table 3: Cyclic scaffolds prepared from fulvenes, grouped according to their applications.

\begin{tabular}{|c|c|c|}
\hline Application & Product & ref \\
\hline \multirow[t]{4}{*}{ complex ligands } & Fischer carbine complexes & {$[87,202,206,207]$} \\
\hline & 1,2-dihydropentalenes & [201] \\
\hline & chromanes & {$[86]$} \\
\hline & cyclopentachromenes & {$[96,165,209]$} \\
\hline \multirow[t]{15}{*}{ natural product skeletons } & 11-heterosteroids & [209] \\
\hline & indans & [199] \\
\hline & anislactones & {$[53,95]$} \\
\hline & marrilactones & [95] \\
\hline & hirsutate & [95] \\
\hline & prostaglandins & [227] \\
\hline & pyranopyrones & [167] \\
\hline & pallambins & [185] \\
\hline & iridoid monoterpenes & [231] \\
\hline & aminocyclopentitols & [53] \\
\hline & 11-oxasteroids & [53] \\
\hline & hirsutane & [53] \\
\hline & histurane & [95] \\
\hline & kigelinol & [125] \\
\hline & kempanes & {$[125]$} \\
\hline \multirow[t]{25}{*}{ biologically active compounds } & azairidoids & [82] \\
\hline & pyrazoline & {$[59,232]$} \\
\hline & azulenes & {$[18,23,93,97,100,121,151,168,198,217-219,223,224,233]$} \\
\hline & dl-senepoxyde & {$[59]$} \\
\hline & indenes & {$[85,99,206,207]$} \\
\hline & pyrazoline & {$[31,47,212]$} \\
\hline & pyrazolines & {$[147,232]$} \\
\hline & diazepines & [158] \\
\hline & quinoxalines & {$[155,158]$} \\
\hline & tricyclopentanoids & [122] \\
\hline & polycycclic cage systems & {$[166,173]$} \\
\hline & eleven-membered carbocycles & [204] \\
\hline & chromophores & [135] \\
\hline & indenes & {$[91,145,208]$} \\
\hline & carboranes & [71] \\
\hline & cyclopentaoxazines & [96] \\
\hline & azapolycycles & [194] \\
\hline & tricyclic scaffolds & {$[89,184]$} \\
\hline & pyridines & {$[92,152,210,211]$} \\
\hline & pyrindines & {$[210,211]$} \\
\hline & 1,4-oxathiins & [164] \\
\hline & iridoid monoterpenes & [231] \\
\hline & dihydropyridines & [92] \\
\hline & piperidines & {$[80,83]$} \\
\hline & cyclooctanoids & {$[89,202-204,209]$} \\
\hline
\end{tabular}

surface binding is amplified. Under optimal conditions, the desired molecule can be isolated in a high, preparative yield [233]. However, this is not always the case, and there are several factors that must be considered when designing a DCL.
All components must be completely soluble, including the products. Failure to achieve this would cause irreversible precipitation of a product, and an inevitable shift in dynamic equilibrium. 
Several types of reversible reactions have been successfully employed in the formation of DCL, including transesterification, peptide bond exchange, disulphide exchange, olefin metathesis and boronic ester formation $[189,233]$. Boul et al. recently investigated the application of fulvene DAC in DCC [189]. While the reaction is reversible, the retro-DAC generally only occurs at higher temperatures, which is not ideal. However, the combination of fulvenes and di- or tricyanoethylenecarboxylates was found to be reversible (and dynamic) under mild conditions at $25-50{ }^{\circ} \mathrm{C}$ (Scheme 18) [189]. At lower temperatures ( -10 to $0{ }^{\circ} \mathrm{C}$ ) the reaction was considerably slower, but overall suggests that certain fulvene DACs can be applied in DCC.

\section{Materials chemistry}

Despite their reactive nature, fulvenes have been successfully used in the formation of several materials, including dynamic polymers (dynamers) [190], hydrogels [191], and precursors to charge-transfer complexes [181,234,235]. Dynamers, referred to as dynamers, are a class of adaptive polymers formed through reversible covalent bonds or noncovalent interactions, allowing continuous modification through bond formation and/ or breaking. This dynamic nature facilitates reorganisation through the exchange of building blocks, or incorporation of new substituents, even after the initial polymer has been formed [192]. The fulvene DAC is a good candidate for dynamer formation, as it is reversible at elevated temperatures [7,192]. A recent study by Reutenauer et al. developed dynamers using DAC of fulvenes (diene) and dicyanofumarate or tricyanoethylenecarboxylate (dienophile) (Scheme 19) [190]. The polymerisation (including the dynamic reversibility) was conducted at room temperature and the resulting polymers were processed as

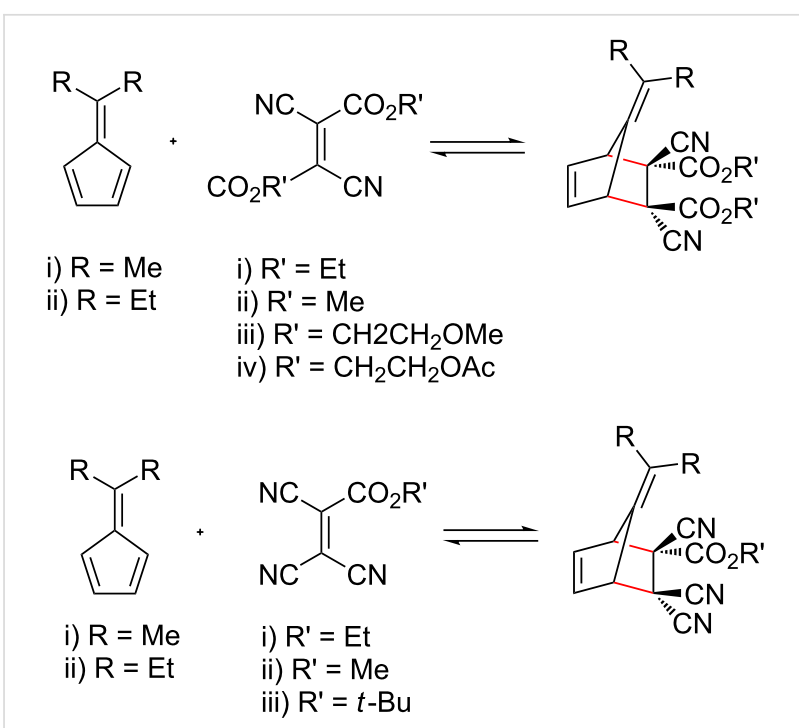

Scheme 18: Schemes for Diels-Alder cycloadditions in dynamic combinatorial chemistry reported by Boul et al. Reactions occur between a pentafulvene and dicyanoethylenecarboxylate or tricyanoethylenecarboxylate [189].

thin films. As a result of the dynamic nature of the Diels-Alder adducts, the films were shown to possess self-healing capabilities [190].

Similarly, Wei et al. employed DAC to create a self-healing hydrogel using a polysaccharide functionalised fulvene as the polydiene. Initially, a fulvene derivative (4-(cyclopenta-2,4dien-1-ylidene)pentanoic acid) was conjugated to dextran, and employed in DAC at $37{ }^{\circ} \mathrm{C}$ with a dichloromaleic acid-modified PEG derivative (Scheme 20) [191].

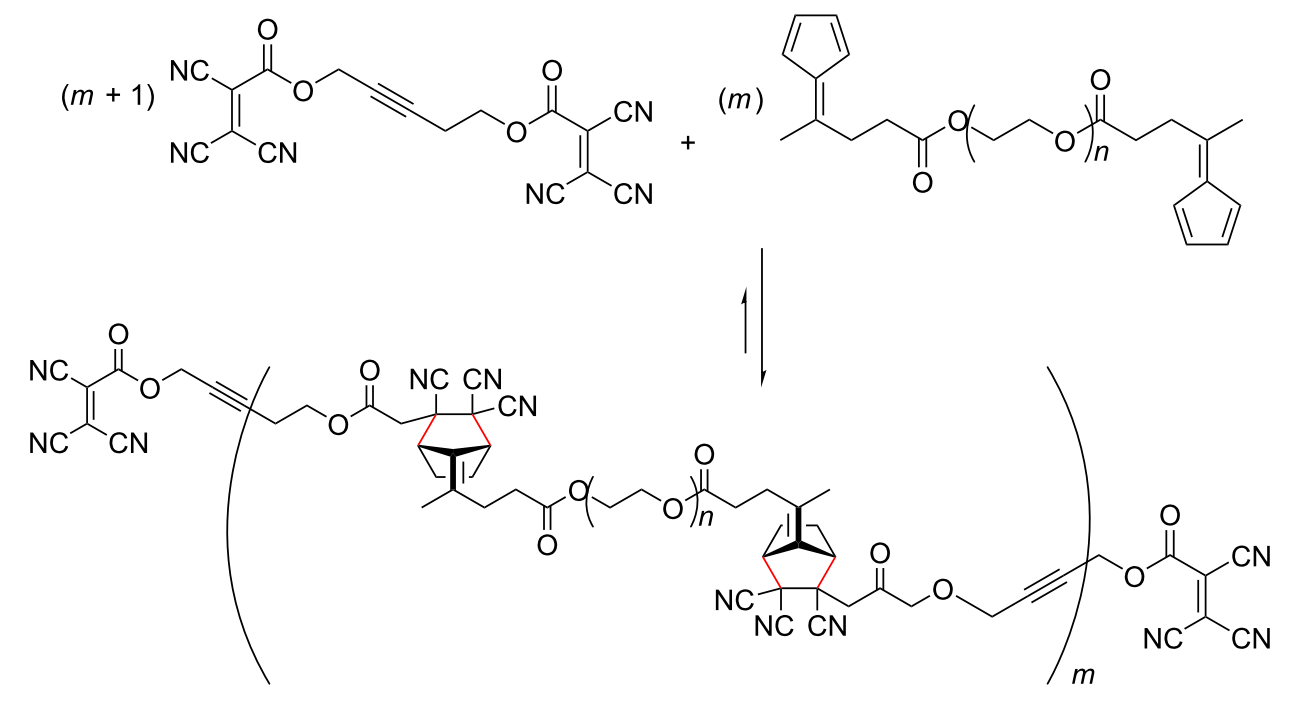

Scheme 19: Polymerisation and dynamer formation via Diels-Alder cycloaddition between fulvene groups in polyethylene glycol bis(fulvene) and bis(tricyanoethylenecarboxylate) derivatives [190]. 

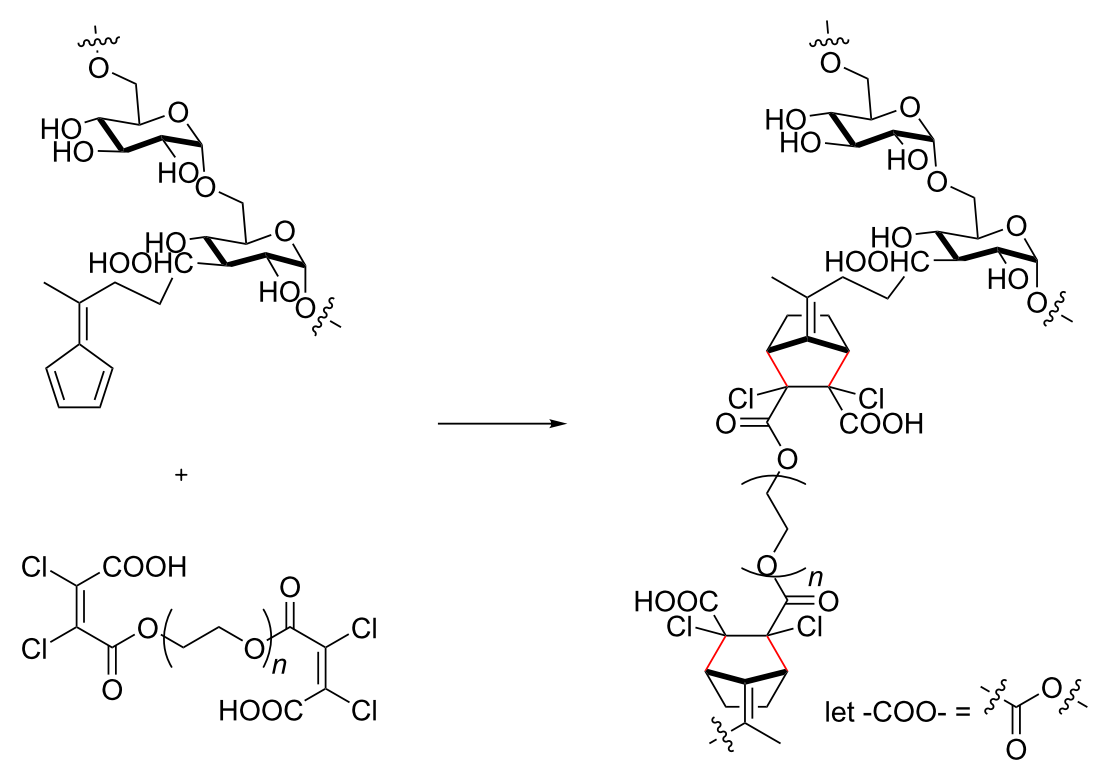

Scheme 20: Preparation of hydrogels via Diels-Alder cycloaddition with fulvene-conjugated dextran and dichloromaleic acid-modified poly(ethylene glycol) [191].

The formed hydrogels exhibited self-healing at physiological temperatures, as well as low levels of cytotoxicity against mouse fibroblast 3T3 cells [191]. With these characteristics in mind, the outlook for these hydrogels having therapeutic applications is promising, with further optimisation [236].

Pentafulvenes have also been used to prepare monomers for ring-opening metathesis polymerisation (ROMP) to generate facially amphiphilic polymers [182,235,237,238]. Ilker et al. employed the DAC between alkyl pentafulvenes and maleic anhydride to initially prepare norbornene anhydride monomers that could be further functionalised to afford norbornene imide monomers (Scheme 21) [105,237]. ROMP of the monomers, followed by deprotection yielded facially amphiphilic polynorbornenes that displayed lipid membrane disruption and antimicrobial activities [237,238].

The facially amphiphilic polynorbornenes with pendent ammonium groups were found to disrupt negatively charged phospholipid unilamellar vesicles at low concentrations $(5 \mu \mathrm{g} / \mathrm{mL})$, and in a dose and molecular weight dependent fashion, indicating their potential antimicrobial properties. Further studies revealed that co-polymerisation of norbornene imide monomers with different alkyl groups provided optimal antimicrobial properties and low haemolytic activities [237].

\section{Conclusion}

This review provides an account of the properties and application of fulvene cycloaddition reactions. The interest in fulvenes due to their unique electronic properties and ability to undergo

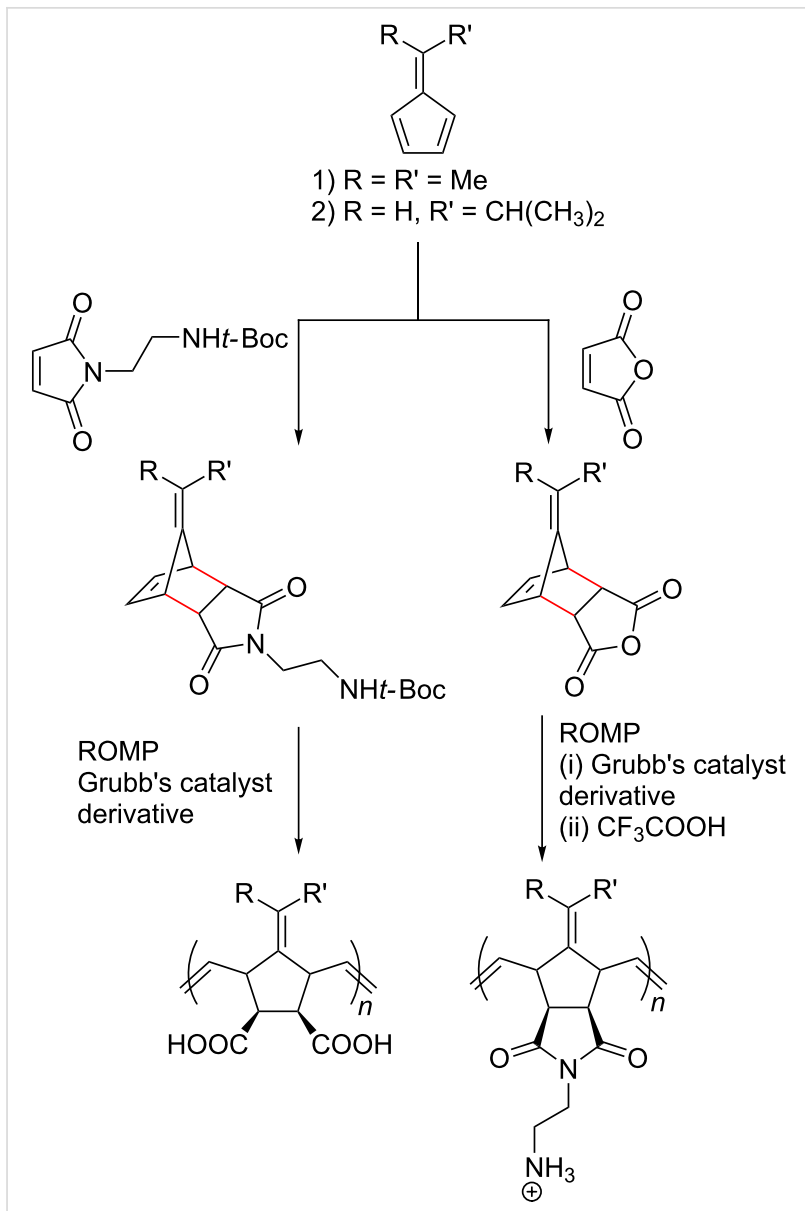

Scheme 21: Ring-opening metathesis polymerisation of norbornene derivatives derived from fulvenes and maleimides to furnish facially amphiphilic polymers. 
multiple highly selective cycloaddition reactions have fuelled advances in organic and natural product synthesis, dynamic combinatorial chemistry and materials science, including dynamers, hydrogels and charge transfer complexes. The recent advances show that potential applications for fulvene cycloaddition reactions are varied and wide in scope. We believe this review will lead to increased interest in these fields, and others yet to be investigated.

\section{Acknowledgements}

$\mathrm{KP}$ and AB kindly acknowledge the Cell Therapies Manufacturing Cooperative Research Centre (CRC) for financial support. ES acknowledges the Division of Health Sciences (University of South Australia) for provision of a high-achiever summer scholarship.

\section{ORCID ${ }^{\circledR}$ iDs}

Ellen Swan - https://orcid.org/0000-0003-1715-2388 Kirsten Platts - https://orcid.org/0000-0003-0155-8877 Anton Blencowe - https://orcid.org/0000-0002-7630-4874

\section{References}

1. Neuenschwander, M. Fulvenes. In Double-Bonded Functional Groups; Patai, S., Ed.; John Wiley \& Sons, Inc.: New York, U.S.A., 1989; Vol. 2, pp 1131-1268. doi:10.1002/9780470772256.ch4

2. Neuenschwander, M. Helv. Chim. Acta 2015, 98, 731-762. doi:10.1002/hlca.201400210

3. Bergmann, E. D. Chem. Rev. 1968, 68, 41-84. doi:10.1021/cr60251a002

4. Billups, W. E.; Gesenberg, C.; Cole, R. Tetrahedron Lett. 1997, 38, 1115-1116. doi:10.1016/s0040-4039(97)00085-3

5. Möllerstedt, H.; Piqueras, M. C.; Crespo, R.; Ottosson, H. J. Am. Chem. Soc. 2004, 126, 13938-13939. doi:10.1021/ja045729c

6. Uebersax, B.; Neuenschwander, M.; Kellerhals, H.-P. Helv. Chim. Acta 1982, 65, 74-88. doi:10.1002/hlca.19820650109

7. Zhang, X.; Lin, F.; Foote, C. S. J. Org. Chem. 1995, 60, 1333-1338. doi:10.1021/jo00110a043

8. Coşkun, N.; Erden, I. Tetrahedron 2011, 67, 8607-8614. doi:10.1016/j.tet.2011.09.036

9. Dahlstrand, C.; Yamazaki, K.; Kilsa, K.; Ottosson, H. J. Org. Chem. 2010, 75, 8060-8068. doi:10.1021/j0101634v

10. Ciabattoni, J.; Nathan, E. C. J. Am. Chem. Soc. 1967, 89, 3081-3082. doi:10.1021/ja00988a070

11. Eicher, T.; Freihoff, W. Synthesis 1986, 908-916. doi:10.1055/s-1986-31821

12. Weber, A.; Neuenschwander, M. Angew. Chem., Int. Ed. Engl. 1981, 20, 774-776. doi:10.1002/anie.198107741

13. Morita, N.; Yokoyama, R.; Asao, T.; Kurita, M.; Kikuchi, S.; Ito, S. J. Organomet. Chem. 2002, 642, 80-90. doi:10.1016/s0022-328x(01)01240-2

14. von E. Doering, W.; Wiley, D. W. Tetrahedron 1960, 11, 183-198. doi:10.1016/0040-4020(60)80069-5

15. Krygowski, T. M.; Oziminski, W. P.; Cyrański, M. K. J. Mol. Model. 2012, 18, 2453-2460. doi:10.1007/s00894-011-1264-4

16. Oda, M.; Kitahara, Y. Angew. Chem., Int. Ed. Engl. 1969, 8, 673-674. doi:10.1002/anie.196906731
17. Liu, C.-Y.; Chen, C.-C.; Shie, Y.-J.; Chung, L.-W.; Cheng, T.-S.; Shie, M.-Y.; Lin, S.-Y.; Tsai, Y.-L. Tetrahedron 2003, 59, 6341-6352. doi:10.1016/s0040-4020(03)00994-3

18. Nair, V.; Anilkumar, G.; Radhakrishnan, K. V.; Nandakumar, M. V.; Kumar, S. Tetrahedron 1997, 53, 15903-15910. doi:10.1016/s0040-4020(97)10051-5

19. Nair, V.; Nandakumar, M. V.; Anilkumar, G.; Eigendorf, G. K. Tetrahedron 1999, 55, 4057-4070. doi:10.1016/s0040-4020(99)00100-3

20. Tsuge, O.; Shiraishi, H.; Noguchi, M. Chem. Lett. 1981, 10, 213-216. doi:10.1246/cl.1981.213

21. Liu, C. Y.; Ding, S. T. J. Org. Chem. 1992, 57, 4539-4544. doi:10.1021/jo00042a039

22. Liu, C.-Y.; Shie, H.-Y.; Yu, C.-L. Tetrahedron 1999, 55, 9171-9184. doi:10.1016/s0040-4020(99)00489-5

23. Yasunami, M.; Kitamori, Y.; Kikuchi, I.; Ohmi, H.; Takase, K. Bull. Chem. Soc. Jpn. 1992, 65, 2127-2130. doi:10.1246/bcsj.65.2127

24. Liu, C. Y.; Ding, S. T.; Chen, S. Y.; You, C. Y.; Shie, H. Y. J. Org. Chem. 1993, 58, 1628-1630. doi:10.1021/jo00058a062

25. Liu, C.-Y.; Houk, K. N. Tetrahedron Lett. 1987, 28, 1367-1370. doi:10.1016/s0040-4039(00)95928-8

26. Mose, R.; Preegel, G.; Larsen, J.; Jakobsen, S.; Iversen, E. H.; Jørgensen, K. A. Nat. Chem. 2017, 9, 487-492. doi:10.1038/nchem.2682

27. Liu, C.-Y.; Smith, D. A.; Houk, K. N. Tetrahedron Lett. 1986, 27 , 4881-4884. doi:10.1016/s0040-4039(00)85087-x

28. Liu, C.-Y.; Shie, H.-Y.; Chen, S.-Y.; You, C.-Y.; Wang, W.-C.; Hua, L.-N.; Yang, H.-J.; Tseng, C.-M. Tetrahedron 1997, 53, 17275-17296. doi:10.1016/s0040-4020(97)10190-9

29. Houk, K. N.; George, J. K.; Duke, R. E., Jr. Tetrahedron 1974, 30 , 523-533. doi:10.1016/s0040-4020(01)96997-2

30. Ruiz-Barragan, S.; Blancafort, L. Faraday Discuss. 2013, 163 , 497-512. doi:10.1039/c3fd20155d

31. Abdelmoniem, A. M.; Abdelhamid, I. A. Curr. Org. Chem. 2016, 20, 1512-1546. doi:10.2174/1385272820666160216224951

32. Kawase, T.; Kurata, H. Recent Developments in Fulvene and Heterofulvene Chemistry. Cross Conjugation; Wiley-VCH Verlag GmbH \& Co. KGaA: Weinheim, Germany, 2016; pp 145-248. doi:10.1002/9783527671182.ch6

33. Preethalayam, P.; Krishnan, K. S.; Thulasi, S.; Chand, S. S.; Joseph, J.; Nair, V.; Jaroschik, F.; Radhakrishnan, K. V. Chem. Rev. 2017, 117, 3930-3989. doi:10.1021/acs.chemrev.6b00210

34. Front Matter. Nomenclature of Organic Chemistry: IUPAC Recommendations and Preferred Names 2013; The Royal Society of Chemistry: Cambridge, United Kingdom, 2014; P001-P004.

35. Setsune, J.-i.; Maeda, S. J. Am. Chem. Soc. 2000, 122, 12405-12406. doi:10.1021/ja005588o

36. Muchowski, J. M.; Scheller, M. E. Synth. Commun. 1987, 17, 863-875. doi:10.1080/00397918708063943

37. Öğretir, C.; Severcan, F. Turk. J. Chem. 1998, 22, 137-142.

38. Watanabe, M.; Kobayashi, T.; Kajigaeshi, S.; Kanemasa, S. Chem. Lett. 1975, 4, 607-610. doi:10.1246/cl.1975.607

39. Chevalier, F.; Geier, G. R., III; Lindsey, J. S. J. Porphyrins Phthalocyanines 2002, 6, 186-197. doi:10.1142/s108842460200021x

40. Abelt, C. J.; Roth, H. D. J. Am. Chem. Soc. 1985, 107, 6814-6818. doi:10.1021/ja00310a012

41. Masuda, Y.; Nakano, T.; Sugiyama, M. J. Phys. Chem. A 2012, 116, 4485-4494. doi:10.1021/jp2110874 
42. Tacke, M.; Fox, S.; Cuffe, L.; Dunne, J. P.; Hartl, F.; Mahabiersing, T. J. Mol. Struct. 2001, 559, 331-339. doi:10.1016/s0022-2860(00)00710-9

43. Dahlstrand, C.; Jahn, B. O.; Grigoriev, A.; Villaume, S.; Ahuja, R.; Ottosson, H. J. Phys. Chem. C 2015, 119, 25726-25737. doi:10.1021/acs.jpcc.5b08042

44. Rentsch, C.; Slongo, M.; Neuenschwander, M. Makromol. Chem. 1978, 179, 1647-1648. doi:10.1002/macp.1978.021790627

45. Rosenberg, M.; Ottosson, H.; Kilså, K. Phys. Chem. Chem. Phys. 2011, 13, 12912-12919. doi:10.1039/c0cp02821e

46. Chand, S. S.; Gopalan, G.; Santhini, P. V.; Preethanuj, P.; John, J.; Harakat, D.; Jaroschik, F.; Radhakrishnan, K. V. Org. Lett. 2016, 18, 964-967. doi:10.1021/acs.orglett.6b00047

47. Adam, W.; Hadjiarapoglou, L. P.; Meffert, A. Tetrahedron Lett. 1991, 32, 6697-6700. doi:10.1016/s0040-4039(00)93578-0

48. Und, M. B.; Neunhoeffer, H. Liebigs Ann. Chem. 1979, 675-688. doi:10.1002/jlac.197919790511

49. Erden, I.; Drummond, J.; Alstad, R.; Xu, F. Tetrahedron Lett. 1993, 34, 1255-1258. doi:10.1016/s0040-4039(00)91767-2

50. Erden, I.; Basada, J.; Poli, D.; Cabrera, G.; Xu, F.; Gronert, S. Tetrahedron Lett. 2016, 57, 2190-2193. doi:10.1016/j.tetlet.2016.04.024

51. Harada, N.; Suzuki, S.; Uda, H.; Ueno, H. J. Am. Chem. Soc. 1972, 94, 1777-1778. doi:10.1021/ja00760a078

52. Harada, N.; Uda, H.; Ueno, H.; Utsumi, S.-i. Chem. Lett. 1973, 2 , 1173-1176. doi:10.1246/cl.1973.1173

53. Skorianetz, W.; Schulte-Elte, K. H.; Ohloff, G. Helv. Chim. Acta 1971, 54, 1913-1922. doi:10.1002/hlca.19710540720

54. Goering, B. K.; Bruce Ganem, J. L. Tetrahedron Lett. 1995, 36, 8905-8908. doi:10.1016/0040-4039(95)01927-a

55. Kohler, E. P.; Kable, J. J. Am. Chem. Soc. 1935, 57, 917-918. doi:10.1021/ja01308a042

56. Blancafort, L.; Gatti, F.; Meyer, H.-D. J. Chem. Phys. 2011, 135, 134303. doi:10.1063/1.3643767

57. Padwa, A.; Nobs, F. Tetrahedron Lett. 1978, 19, 93-96. doi:10.1016/s0040-4039(01)85052-8

58. Kedziorek, M.; Mayer, P.; Mayr, H. Eur. J. Org. Chem. 2009, 1202-1206. doi:10.1002/ejoc.200801099

59. Rentsch, C.; Slongo, M.; Schönholzer, S.; Neuenschwander, M. Makromol. Chem. 1980, 181, 19-29. doi:10.1002/macp.1980.021810102

60. Ichihara, A.; Oda, K.; Kobayashi, M.; Sakamura, S. Tetrahedron Lett. 1974, 15, 4235-4238. doi:10.1016/s0040-4039(01)92130-6

61. Bearpark, M. J.; Bernardi, F.; Olivucci, M.; Robb, M. A.; Smith, B. R. J. Am. Chem. Soc. 1996, 118, 5254-5260. doi:10.1021/ja9542799

62. Jenkins, S.; Blancafort, L.; Kirk, S. R.; Bearpark, M. J. Phys. Chem. Chem. Phys. 2014, 16, 7115-7126. doi:10.1039/c4cp00003j

63. Mendive-Tapia, D.; Lasorne, B.; Worth, G. A.; Bearpark, M. J.; Robb, M. A. Phys. Chem. Chem. Phys. 2010, 12, 15725-15733. doi:10.1039/c0cp01757d

64. Noorizadeh, S.; Shakerzadeh, E. Comput. Theor. Chem. 2011, 964, 141-147. doi:10.1016/j.comptc.2010.12.012

65. Chandrasekhar, S.; Sridharan, R. J. Chem. Res., Synop. 2001, 511. doi:10.3184/030823401103168893

66. Sinnema, P.-J.; Höhn, B.; Hubbard, R. L.; Shapiro, P. J.; Twamley, B.; Blumenfeld, A.; Vij, A. Organometallics 2002, 21, 182-191. doi:10.1021/om010614s
67. Krygowski, T. M.; Oziminski, W. P.; Palusiak, M.; Fowler, P. W.; McKenzie, A. D. Phys. Chem. Chem. Phys. 2010, 12, 10740-10745. doi:10.1039/c003686b

68. Patai, S., Ed. The Chemistry of Double-Bonded Functional Groups; The Chemistry of Functional Groups, Vol. 2; John Wiley \& Sons, Ltd: Chichester, United Kingdom, 2010.

69. Strohfeldt, K.; Tacke, M. Chem. Soc. Rev. 2008, 37, 1174-1187. doi:10.1039/b707310k

70. Peloquin, A. J.; Stone, R. L.; Avila, S. E.; Rudico, E. R.; Horn, C. B.; Gardner, K. A.; Ball, D. W.; Johnson, J. E. B.; lacono, S. T.; Balaich, G. J. J. Org. Chem. 2012, 77, 6371-6376. doi:10.1021/jo301101x

71. Gugelchuk, M. M.; Chan, P. C.-M.; Sprules, T. J. J. Org. Chem. 1994, 59, 7723-7731. doi:10.1021/j000104a031

72. Zhang, J.; Qiu, Z.; Xu, P.-F.; Xie, Z. ChemPlusChem 2014, 79, 1044-1052. doi:10.1002/cplu.201402129

73. Caramella, P.; Frattini, P.; Grünanger, P. Tetrahedron Lett. 1971, 12, 3817-3820. doi:10.1016/s0040-4039(01)97297-1

74. Paddon-Row, M. N.; Gell, K.; Warrener, R. N. Tetrahedron Lett. 1975, 16, 1975-1978. doi:10.1016/s0040-4039(00)72338-0

75. Krishnan, K. S.; Rajan, R.; Radhakrishnan, K. V. Synthesis 2008, 1955-1959. doi:10.1055/s-2008-1067093

76. Kato, H.; Aoki, N.; Kawamura, Y.; Yoshino, K. J. Chem. Soc., Perkin Trans. 1 1985, 1245-1247. doi:10.1039/p19850001245

77. Hitoshi, T.; Akira, M.; Sansei, S.; Yutaka, F. Bull. Chem. Soc. Jpn. 1975, 48, 1661-1662.

78. Machiguchi, T.; Hasegawa, T.; Ishii, Y.; Yamabe, S.; Minato, T. J. Am. Chem. Soc. 1993, 115, 11536-11541. doi:10.1021/ja00077a060

79. Saito, T.; Musashi, T.; Motoki, S. Bull. Chem. Soc. Jpn. 1980, 53, 3377-3378. doi:10.1246/bcsj.53.3377

80. Gupta, Y. N.; Doa, M. J.; Houk, K. N. J. Am. Chem. Soc. 1982, 104, 7336-7338. doi:10.1021/ja00389a083

81. Potowski, M.; Bauer, J. O.; Strohmann, C.; Antonchick, A. P.; Waldmann, H. Angew. Chem., Int. Ed. 2012, 51, 9512-9516. doi:10.1002/anie.201204394

82. Potowski, M.; Antonchick, A. P.; Waldmann, H. Chem. Commun. 2013, 49, 7800-7802. doi:10.1039/c3cc43824d

83. Narayan, R.; Potowski, M.; Jia, Z.-J.; Antonchick, A. P.; Waldmann, H. Acc. Chem. Res. 2014, 47, 1296-1310. doi:10.1021/ar400286b

84. He, Z.-L.; Teng, H.-L.; Wang, C.-J. Angew. Chem., Int. Ed. 2013, 52, 2934-2938. doi:10.1002/anie.201208799

85. Hayashi, Y.; Gotoh, H.; Honma, M.; Sankar, K.; Kumar, I.; Ishikawa, H.; Konno, K.; Yui, H.; Tsuzuki, S.; Uchimaru, T. J. Am. Chem. Soc. 2011, 133, 20175-20185. doi:10.1021/ja108516b

86. Barluenga, J.; Martínez, S. ARKIVOC 2006, №. vii, 129-147.

87. Zhang, J.; Lin, L.; He, C.; Xiong, Q.; Liu, X.; Feng, X. Chem. Commun. 2018, 54, 74-77. doi:10.1039/c7cc08124c

88. Barluenga, J.; Martínez, S.; Suárez-Sobrino, A. L.; Tomás, M. J. Am. Chem. Soc. 2002, 124, 5948-5949. doi:10.1021/ja0260667

89. Friedrichsen, W.; Betz, M.; Büldt, E.; Jürgens, H.-J.; Schmidt, R.; Schwarz, I.; Visser, K. Justus Liebigs Ann. Chem. 1978, 440-472. doi:10.1002/jlac.197819780310

90. Krishnan, K. S.; Suresh, E.; Mathew, S.; Radhakrishnan, K. V. Synthesis 2006, 1811-1818. doi:10.1055/s-2006-942366

91. Manikandan, S.; Shanmugasundaram, M.; Raghunathan, R. Tetrahedron 2002, 58, 597-601. doi:10.1016/s0040-4020(01)01174-7

92. Tseng, H.-C.; Gupta, A. K.; Hong, B.-C.; Liao, J.-H. Tetrahedron 2006, 62, 1425-1432. doi:10.1016/j.tet.2005.11.029 
93. He, Z.-L.; Wang, C.-J. Chem. Commun. 2015, 51, 534-536. doi:10.1039/c4cc08382b

94. Kato, H.; Kobayashi, T.; Ciobanu, M.; Kakehi, A. Tetrahedron 1997, 53, 9921-9934. doi:10.1016/s0040-4020(97)00337-2

95. Alder, K.; Flock, F. H.; Lessenich, H. Chem. Ber. 1957, 90, 1709-1720. doi:10.1002/cber.19570900903

96. Hong, B.-C.; Shr, Y.-J.; Wu, J.-L.; Gupta, A. K.; Lin, K.-J. Org. Lett. 2002, 4, 2249-2252. doi:10.1021/ol026103z

97. Hong, B.-C.; Sun, H.-I.; Chen, Z.-Y. Chem. Commun. 1999, 2125-2126. doi:10.1039/a906877e

98. Cho, S.-Y.; Kang, S.-K.; Ahn, J.-H.; Ha, J.-D.; Yon, G.-H.; Choi, J.-K. Bull. Korean Chem. Soc. 2006, 27, 1481-1484.

99. Hong, B.-C.; Sun, S.-S. Chem. Commun. 1996, 937-938. doi:10.1039/cc9960000937

100.Hong, B.-C.; Sun, S.-s. Tetrahedron Lett. 1996, 37, 659-662. doi:10.1016/0040-4039(95)02226-0

101. Houk, K. N. Acc. Chem. Res. 1975, 8, 361-369. doi:10.1021/ar50095a001

102.Dunn, L. C.; Chang, Y.-M.; Houk, K. N. J. Am. Chem. Soc. 1976, 98 7095-7096. doi:10.1021/ja00438a068

103.Sadlej-Sosnowska, N. Struct. Chem. 2018, 29, 23-31. doi:10.1007/s11224-017-0995-y

104.Krygowski, T. M.; Cyrański, M. K. Chem. Rev. 2001, 101, 1385-1420. doi:10.1021/cr990326u

105.Muthusamy, S.; Babu, S. A.; Gunanathan, C.; Suresh, E.; Dastidar, P. Synlett 2001, 1407-1410. doi:10.1055/s-2001-16778

106. Houk, K. N.; Luskus, L. J.; Bhacca, N. S. J. Am. Chem. Soc. 1970, 92, 6392-6394. doi:10.1021/ja00724a077

107.Yu, P.; Chen, T. Q.; Yang, Z.; He, C. Q.; Patel, A.; Lam, Y.-h.; Liu, C.-Y.; Houk, K. N. J. Am. Chem. Soc. 2017, 139, 8251-8258. doi:10.1021/jacs.7b02966

108. Escher, A.; Rutsch, W.; Neuenschwander, M. Helv. Chim. Acta 1986, 69, 1644-1654. doi:10.1002/hlca.19860690719

109. Niggli, U.; Neuenschwander, M. Helv. Chim. Acta 1990, 73, 2199-2208. doi:10.1002/hlca.19900730817

110.Uebersax, B.; Neuenschwander, M.; Engel, P. Helv. Chim. Acta 1982, 65, 89-104. doi:10.1002/hlca.19820650110

111.Slongo, M.; Schönholzer, S.; Rentsch, C.; Neuenschwander, M. Makromol. Chem. 1980, 181, 31-36. doi:10.1002/macp.1980.021810103

112. Warrener, R. N.; Hammond, M. L. A.; Butler, D. N. Synth. Commun. 2001, 31, 1167-1175. doi:10.1081/scc-100104000

113. Hafner, K. Pure Appl. Chem. 1990, 62, 531-540. doi:10.1351/pac199062030531

114. Houk, K. N.; Luskus, L. J. J. Org. Chem. 1973, 38, 3836-3843. doi:10.1021/jo00962a005

115.Andrew, T. L.; Cox, J. R.; Swager, T. M. Org. Lett. 2010, 12, 5302-5305. doi:10.1021/ol102384k

116.Mömming, C. M.; Kehr, G.; Fröhlich, R.; Erker, G. Chem. Commun. 2011, 47, 2006-2007. doi:10.1039/c0cc04567e

117.Hong, B.-C.; Shr, Y.-J.; Liao, J.-H. Org. Lett. 2002, 4, 663-666. doi:10.1021/ol017304q

118.Stepakov, A. V.; Boitsov, V. M.; Larina, A. G.; Molchanov, A. P. Russ. J. Org. Chem. 2014, 50, 389-393. doi:10.1134/s1070428014030154

119.Shanmugasundaram, M.; Raghunathan, R. Tetrahedron Lett. 1999, 40, 4869-4870. doi:10.1016/s0040-4039(99)00898-9

120. Rideout, D. C.; Breslow, R. J. Am. Chem. Soc. 1980, 102, 7816-7817. doi:10.1021/ja00546a048

121. Kumar, A. Chem. Rev. 2001, 101, 1-20. doi:10.1021/cr990410+
122. Kitano, H.; Fujita, S.; Takehara, Y.; Hattori, M.; Morita, T.; Matsumoto, K.; Hatanaka, M. Tetrahedron 2003, 59, 2673-2677. doi:10.1016/s0040-4020(03)00297-7

123. Gupta, Y. N.; Patterson, R. T.; Bimanand, A. Z.; Houk, K. N. Tetrahedron Lett. 1986, 27, 295-298. doi:10.1016/s0040-4039(00)84000-9

124.Wu, T. C.; Houk, K. N. J. Am. Chem. Soc. 1985, 107, 5308-5309. doi:10.1021/ja00304a065

125.Wu, T. C.; Mareda, J.; Gupta, Y. N.; Houk, K. N. J. Am. Chem. Soc. 1983, 105, 6996-6997. doi:10.1021/ja00361a060

126.Liu, C.-Y.; Houk, K. N. Tetrahedron Lett. 1987, 28, 1371-1374. doi:10.1016/s0040-4039(00)95929-x

127.Hong, B.-C.; Chen, F.-L.; Chen, S.-H.; Liao, J.-H.; Lee, G.-H. Org. Lett. 2005, 7, 557-560. doi:10.1021/ol047730m

128. Akunyili, D. N.; Houghton, P. J. Phytochemistry 1993, 32, 1015-1018. doi:10.1016/0031-9422(93)85246-n

129. Moideen, S. V. K.; Houghton, P. J.; Rock, P.; Croft, S. L.; Aboagye-Nyame, F. Planta Med. 1999, 65, 536-540. doi:10.1055/s-1999-14011

130. König, G. M.; Wright, A. D.; Angerhofer, C. K. J. Org. Chem. 1996, 61 3259-3267. doi:10.1021/jo952015z

131.Prestwich, G. D. Insect Biochem. 1979, 9, 563-567. doi:10.1016/0020-1790(79)90093-3

132.Stadler, H.; Rey, M.; Dreiding, A. S. Helv. Chim. Acta 1984, 67, 1379-1385. doi:10.1002/hlca.19840670525

133. Parvulescu, L.; Marton, A.; Mihai, M.; Draghici, C.; Varga, R.; Gheorghiu, M. D. Rev. Roum. Chim. 2009, 54, 895-902.

134. Asao, T.; Machiguchi, T.; Kitamura, T.; Kitahara, Y. J. Chem. Soc. D 1970, 89-90. doi:10.1039/c29700000089

135. Finke, A. D.; Dumele, O.; Zalibera, M.; Confortin, D.; Cias, P.; Jayamurugan, G.; Gisselbrecht, J.-P.; Boudon, C.; Schweizer, W. B.; Gescheidt, G.; Diederich, F. J. Am. Chem. Soc. 2012, 134, 18139-18146. doi:10.1021/ja309141r

136. Finke, A. D.; Diederich, F. Chem. Rec. 2015, 15, 19-30. doi:10.1002/tcr.201402060

137. Jayamurugan, G.; Dumele, O.; Gisselbrecht, J.-P.; Boudon, C.; Schweizer, W. B.; Bernet, B.; Diederich, F. J. Am. Chem. Soc. 2013, 135, 3599-3606. doi:10.1021/ja312084s

138. Friedrichsen, W.; Seidel, W.; Debaerdemaeker, T. J. Heterocycl. Chem. 1983, 20, 1621-1628. doi:10.1002/jhet.5570200639

139. Harmon, R. E.; Barta, W. D.; Gupta, S. K.; Slomp, G. J. Chem. Soc. D 1970, 935-936. doi:10.1039/c29700000935

140. Tolstikov, G. A.; Miftakhov, M. S.; Akhametvaleev, R. R.; Khalikov, L. M. Zh. Org. Khim. 1986, 22, 1555-1556.

141.Djapa, F.; Ciamala, K.; Vebrel, J.; Kubicki, M. M.; Blacque, O. Acta Crystallogr., Sect. C: Cryst. Struct. Commun. 1999, 55, 677-678. doi:10.1107/s0108270198015947

142. Chandrasekhar, S.; Ravindranath, M.; Neela, B. S.; Ramakuma, S.; Viswamitra, M. J. Chem. Res., Synop. 1989, 8, 252-253.

143. Nair, V.; Nandakumar, M. V.; Maliakal, D.; Mathen, J. S.; Rath, N. P. Tetrahedron 2000, 56, 8001-8005. doi:10.1016/s0040-4020(00)00718-3

144.Chu, J.-H.; Li, W.-S.; Chao, I.; Lee, G.-H.; Chung, W.-S. Tetrahedron 2006, 62, 7380-7389. doi:10.1016/j.tet.2006.05.021

145. Kuthanapillil, J. M.; Nijamudheen, A.; Joseph, N.; Prakash, P.; Suresh, E.; Datta, A.; Radhakrishnan, K. V. Tetrahedron 2013, 69, 9751-9760. doi:10.1016/j.tet.2013.09.016

146. Djapa, F.; Ciamala, K.; Melot, J.-M.; Vebrel, J.; Herlem, G. J. Chem. Soc., Perkin Trans. 1 2002, 687-695. doi:10.1039/b106892j 
147.Santhini, P. V.; Sarath Chand, S.; John, J.; Varma, R. L.; Jaroschik, F.; Radhakrishnan, K. V. Synlett 2017, 28, 951-956. doi:10.1055/s-0036-1588696

148. Debaerdemaeker, T.; Schröer, W.-D.; Friedrichsen, W. Liebigs Ann. Chem. 1981, 502-520. doi:10.1002/jlac.198119810316

149.Dhar, D. N.; Ragunathan, R. Tetrahedron 1984, 40, 1585-1590. doi:10.1016/s0040-4020(01)91808-3

150.Nair, V.; Anilkumar, G.; Radhakrishnan, K. V.; Sheela, K. C.; Rath, N. P. Tetrahedron 1997, 53, 17361-17372. doi:10.1016/s0040-4020(97)10160-0

151.Paddon-Row, M.; Patney, H.; Warrener, R. Aust. J. Chem. 1977, 30, 2307-2311. doi:10.1071/ch9772307

152. Lewis, N. J.; Collins, W. J.; Knight, D. B. J. Med. Chem. 1979, 22 , 1505-1509. doi:10.1021/jm00198a014

153.Bimanand, A. Z.; Gupta, Y. N.; Doa, M. J.; Eaton, T. A.; Houk, K. N.; Fronczek, F. R. J. Org. Chem. 1983, 48, 403-405. doi:10.1021/jo00151a032

154.Hong, B.-C.; Wu, J.-L.; Gupta, A. K.; Hallur, M. S.; Liao, J.-H. Org. Lett. 2004, 6, 3453-3456. doi:10.1021/ol048762c

155. Banerjee, S.; Soldevila-Barreda, J. J.; Wolny, J. A.; Wootton, C. A.; Habtemariam, A.; Romero-Canelón, I.; Chen, F.; Clarkson, G. J.; Prokes, I.; Song, L.; O'Connor, P. B.; Schünemann, V.; Sadler, P. J. Chem. Sci. 2018, 9, 3177-3185. doi:10.1039/c7sc05058e

156. Nair, V.; Kumar, S.; Anilkumar, G.; Somarajan Nair, J. Tetrahedron 1995, 51, 9155-9166. doi:10.1016/0040-4020(95)00512-7

157.Friedrichsen, W.; Oeser, H.-G. Justus Liebigs Ann. Chem. 1978, 1139-1145. doi:10.1002/jlac.197819780713

158. Friedrichsen, W.; Oeser, H.-G. Justus Liebigs Ann. Chem. 1978, 1161-1186. doi:10.1002/jlac.197819780715

159.Allmann, R.; Debaerdemaeker, T.; Friedrichsen, W.; Jürgens, H. J.; Betz, M. Tetrahedron 1976, 32, 147-157. doi:10.1016/0040-4020(76)80035-x

160. Friedrichsen, W.; Oeser, H.-G. Justus Liebigs Ann. Chem. 1978, 1146-1160. doi:10.1002/jlac.197819780714

161.Friedrichsen, W.; Schröer, W.-D.; Schmidt, R. Justus Liebigs Ann. Chem. 1976, 793-819. doi:10.1002/jlac.197619760502

162. Nair, V.; Kumar, S. Tetrahedron 1996, 52, 4029-4040. doi:10.1016/s0040-4020(96)00067-1

163. Friedrichsen, W.; Büldt, E.; Betz, M.; Schmidt, R. Tetrahedron Lett. 1974, 15, 2469-2472. doi:10.1016/s0040-4039(01)92289-0

164.Nair, V.; Kumar, S.; Williard, P. G. Tetrahedron Lett. 1995, 36, 1605-1608. doi:10.1016/0040-4039(95)00099-x

165. Friedrichsen, W.; Oeser, H.-G. Tetrahedron Lett. 1974, 15 , 4373-4376. doi:10.1016/s0040-4039(01)92167-7

166. Nair, V.; Mathew, B. Tetrahedron Lett. 2000, 41, 6919-6921. doi:10.1016/s0040-4039(00)01146-1

167.Hong, B.-C.; Shen, I.-C.; Liao, J.-H. Tetrahedron Lett. 2001, 42, 935-938. doi:10.1016/s0040-4039(00)02139-0

168.James, B.; Suresh, E.; Nair, M. S. Synlett 2006, 3479-3483. doi:10.1055/s-2006-956481

169.Nair, V.; Jayan, C. N.; Radhakrishnan, K. V.; Anilkumar, G.; Rath, N. P. Tetrahedron 2001, 57, 5807-5813. doi:10.1016/s0040-4020(01)00471-9

170.Sato, M.; Ebine, S.; Tsunetsugu, J. Tetrahedron Lett. 1974, 15, 2769-2770. doi:10.1016/s0040-4039(01)91737-x

171.Tsuge, O.; Takata, T.; Noguchi, M. Chem. Lett. 1980, 9, 1031-1034. doi:10.1246/cl.1980.1031
172.Saranya, S.; Baiju, T. V.; Gopalan, G.; Radhakrishnan, K. V. Synth. Commun. 2018, 48, 816-829. doi:10.1080/00397911.2018.1427270

173. Friedrichsen, W.; Schröer, W.-D. Liebigs Ann. Chem. 1981, 476-490. doi:10.1002/jlac.198119810314

174. Tolstikov, G. A.; Lerman, B. M.; Belogaeva, T. A. Bull. Acad. Sci. USSR, Div. Chem. Sci. (Engl. Transl.) 1990, 38, 1561-1563. doi:10.1007/bf00978462

175. Griesbeck, A. G. Tetrahedron Lett. 1988, 29, 3477-3480. doi:10.1016/0040-4039(88)85194-3

176. Ondrus, V.; Fisera, L.; Polborn, K.; Ertl, P.; Prónayová, N. Monatsh. Chem. 1995, 126, 961-969. doi:10.1007/bf00811016

177. Fox, M. A.; Cardona, R.; Kiwiet, N. J. J. Org. Chem. 1987, 52, 1469-1474. doi:10.1021/jo00384a016

178. Nzabamwita, G.; Kolani, B.; Jousseaume, B. Tetrahedron Lett. 1989, 30, 2207-2208. doi:10.1016/s0040-4039(00)99649-7

179. Lonergan, D. G.; Deslongchamps, G. Tetrahedron 1998, 54, 14041-14052. doi:10.1016/s0040-4020(98)00881-3

180.Woodward, R. B.; Baer, H. J. Am. Chem. Soc. 1944, 66, 645-649. doi:10.1021/ja01232a042

181.Colak, S.; Nelson, C. F.; Nüsslein, K.; Tew, G. N. Biomacromolecules 2009, 10, 353-359. doi:10.1021/bm801129y

182. Ilker, M. F.; Schule, H.; Coughlin, E. B. Macromolecules 2004, 37, 694-700. doi:10.1021/ma035407d

183.Öcal, N.; Bağdatli, E.; Arslan, M. Turk. J. Chem. 2005, 29, 7-16.

184. Dieckmann, A.; Beniken, S.; Lorenz, C. D.; Doltsinis, N. L.; von Kiedrowski, G. Chem. - Eur. J. 2011, 17, 468-480. doi:10.1002/chem.201002325

185. Yates, P.; Lokensgard, J. P. Synth. Commun. 1975, 5, 37-42. doi:10.1080/00397917508063513

186. Howard, M. H.; Alexander, V.; Marshall, W. J.; Roe, D. C.; Zheng, Y.-J. J. Org. Chem. 2003, 68, 120-129. doi:10.1021/j00265333

187. Ebner, C.; Carreira, E. M. Angew. Chem., Int. Ed. 2015, 54, 11227-11230. doi:10.1002/anie.201505126

188. Siegel, H. Synthesis 1985, 798-801. doi:10.1055/s-1985-31356

189. Boul, P. J.; Reutenauer, P.; Lehn, J.-M. Org. Lett. 2005, 7, 15-18. doi:10.1021/ol048065k

190. Reutenauer, P.; Buhler, E.; Boul, P. J.; Candau, S. J.; Lehn, J.-M. Chem. - Eur. J. 2009, 15, 1893-1900. doi:10.1002/chem.200802145

191. Wei, Z.; Yang, J. H.; Du, X. J.; Xu, F.; Zrinyi, M.; Osada, Y.; Li, F.; Chen, Y. M. Macromol. Rapid Commun. 2013, 34, 1464-1470. doi:10.1002/marc.201300494

192. Roy, N.; Bruchmann, B.; Lehn, J.-M. Chem. Soc. Rev. 2015, 44, 3786-3807. doi:10.1039/c5cs00194c

193. Haq, M. Z. J. Org. Chem. 1972, 37, 3015-3019. doi:10.1021/jo00984a023

194.Sasaki, T.; Hayakawa, K.; Manabe, T.; Nishida, S.; Wakabayashi, E. J. Org. Chem. 1981, 46, 2021-2024. doi:10.1021/jo00323a010

195. Olsen, H. Angew. Chem., Int. Ed. Engl. 1982, 21, 383-384. doi:10.1002/anie.198203831

196. Anas, S.; Krishnan, K. S.; Sajisha, V. S.; Anju, K. S.; Radhakrishnan, K. V.; Suresh, E.; Suresh, C. H. New J. Chem. 2007, 31, 237-246. doi:10.1039/b614533g

197.Bhojgude, S. S.; Kaicharla, T.; Bhunia, A.; Biju, A. T. Org. Lett. 2012, 14, 4098-4101. doi:10.1021/ol301742k

198. Muneyuki, R.; Tanida, H. J. Org. Chem. 1966, 31, 1988-1990. doi:10.1021/jo01344a517 
199. Hankinson, B.; Heaney, H.; Price, A. P.; Sharma, R. P. J. Chem. Soc., Perkin Trans. 1 1973, 2569-2575. doi:10.1039/p19730002569

200.Dunn, L. C.; Houk, K. N. Tetrahedron Lett. 1978, 19, 3411-3414. doi:10.1016/s0040-4039(00)70533-8

201.Hong, B.-c.; Sun, S.-s.; Tsai, Y.-c. J. Org. Chem. 1997, 62, 7717-7725. doi:10.1021/jo970984j

202.Suda, M.; Hafner, K. Tetrahedron Lett. 1977, 18, 2449-2452. doi:10.1016/s0040-4039(01)83790-4

203. Coşkun, N.; Ma, J.; Azimi, S.; Gärtner, C.; Erden, I. Org. Lett. 2011, 13, 5952-5955. doi:10.1021/ol202222d

204.Krishnan, K. S.; Sajisha, V. S.; Anas, S.; Suresh, C. H.; Bhadbhade, M. M.; Bhosekar, G. V.; Radhakrishnan, K. V. Tetrahedron 2006, 62, 5952-5961. doi:10.1016/j.tet.2006.04.017

205.Radhakrishnan, K. V.; Syam Krishnan, K.; Bhadbhade, M. M.; Bhosekar, G. V. Tetrahedron Lett. 2005, 46, 4785-4788. doi:10.1016/j.tetlet.2005.05.042

206. Krishnan, K. S.; Kuthanapillil, J. M.; Rajan, R.; Suresh, E.; Radhakrishnan, K. V. Eur. J. Org. Chem. 2007, 5847-5851. doi:10.1002/ejoc.200700767

207.Krishnan, K. S.; Smitha, M.; Suresh, E.; Radhakrishnan, K. V. Tetrahedron 2006, 62, 12345-12350. doi:10.1016/j.tet.2006.09.102

208.Barluenga, J.; Martınez, S.; Suárez-Sobrino, A. L.; Tomás, M. J. Organomet. Chem. 2005, 690, 5696-5700. doi:10.1016/j.jorganchem.2005.07.017

209. Barluenga, J.; Martínez, S.; Suárez-Sobrino, A. L.; Tomás, M. J. Am. Chem. Soc. 2001, 123, 11113-11114. doi:10.1021/ja011600g

210.Hong, B.-C.; Chen, Z.-Y.; Chen, W.-H. Org. Lett. 2000, 2, 2647-2649. doi:10.1021/ol006180z

211.Hong, B.-C.; Chen, Z.-Y.; Chen, W.-H.; Sun, H.-I.; Lee, G.-H. J. Chin. Chem. Soc. 2005, 52, 181-200. doi:10.1002/jccs.200500028

212.Hong, B.-C.; Gupta, A. K.; Wu, M.-F.; Liao, J.-H. Tetrahedron Lett. 2004, 45, 1663-1666. doi:10.1016/j.tetlet.2003.12.105

213.Hong, B.-C.; Gupta, A. K.; Wu, M.-F.; Liao, J.-H.; Lee, G.-H. Org. Lett. 2003, 5, 1689-1692. doi:10.1021/ol034329b

214.Lee, K. J.; Choi, J.-K.; Yum, E. K.; Cho, S. Y. Tetrahedron Lett. 2009, 50, 6698-6700. doi:10.1016/j.tetlet.2009.09.086

215. Friedrichsen, W.; Oeser, H.-G. Tetrahedron Lett. 1975, 16 , 1489-1492. doi:10.1016/s0040-4039(00)72176-9

216. Hong, B.-C.; Jiang, Y.-F.; Kumar, E. S. Bioorg. Med. Chem. Lett. 2001, 11, 1981-1984. doi:10.1016/s0960-894x(01)00349-3

217. Houk, K. N.; Luskus, L. J.; Bhacca, N. S. Tetrahedron Lett. 1972, 13, 2297-2300. doi:10.1016/s0040-4039(01)84832-2

218. Russell, D. H.; Gross, M. L. J. Am. Chem. Soc. 1980, 102, 6279-6284. doi:10.1021/ja00540a017

219.Gupta, Y. N.; Mani, S. R.; Houk, K. N. Tetrahedron Lett. 1982, 23 , 495-498. doi:10.1016/s0040-4039(00)86871-9

220.Mukherjee, D.; Dunn, L. C.; Houk, K. N. J. Am. Chem. Soc. 1979, 101, 251-252. doi:10.1021/ja00495a058

221. Moiseev, A. M.; Balenkova, E. S.; Nenajdenko, V. G. Russ. Chem. Bull. 2006, 55, 141-146. doi:10.1007/s11172-006-0227-x

222. Reiter, S. E.; Dunn, L. C.; Houk, K. N. J. Am. Chem. Soc. 1977, 99, 4199-4201. doi:10.1021/ja00454a070

223. Amir, E.; Amir, R. J.; Campos, L. M.; Hawker, C. J. J. Am. Chem. Soc. 2011, 133, 10046-10049. doi:10.1021/ja203267g

224.Copland, D.; Leaver, D.; Menzies, W. B. Tetrahedron Lett. 1977, 18, 639-640. doi:10.1016/s0040-4039(01)92713-3

225. Messmer, A.; Hajós, G.; Timári, G. Monatsh. Chem. 1988, 119, 1113-1119. doi:10.1007/bf00809263
226. Mori, M.; Kanematsu, K. J. Chem. Soc., Chem. Commun. 1980 , 873-874. doi:10.1039/c39800000873

227. Nair, V.; Abhilash, K. G.; Zeimer, B. Tetrahedron Lett. 2005, 46, 2307-2309. doi:10.1016/j.tetlet.2005.02.014

228. Sakai, K.; Kobori, T.; Fujisawa, T. Tetrahedron Lett. 1981, 22 , 115-118. doi:10.1016/0040-4039(81)80163-3

229. Paquette, L. A.; Kravetz, T. M.; Böhm, M. C.; Gleiter, R. J. Org. Chem. 1983, 48, 1250-1257. doi:10.1021/jo00156a021

230.Aqad, E.; Leriche, P.; Mabon, G.; Gorgues, A.; Khodorkovsky, V. Org. Lett. 2001, 3, 2329-2332. doi:10.1021/ol016143n

231. Dieckmann, A.; Beniken, S.; Lorenz, C.; Doltsinis, N. L.; von Kiedrowski, G. J. Syst. Chem. 2010, 1, No. 10. doi:10.1186/1759-2208-1-10

232. Nicolaou, K. C.; Snyder, S. A.; Montagnon, T.; Vassilikogiannakis, G. Angew. Chem., Int. Ed. 2002, 41, 1668-1698. doi:10.1002/1521-3773(20020517)41:10<1668::aid-anie1668>3.0.co; $2-z$

233. Otto, S.; Furlan, R. L. E.; Sanders, J. K. M. Drug Discovery Today 2002, 7, 117-125. doi:10.1016/s1359-6446(02)00006-5

234. Inagi, S.; Naka, K.; Chujo, Y. J. Polym. Sci., Part A: Polym. Chem. 2007, 45, 3770-3775. doi:10.1002/pola.22128

235. Godman, N. P.; Balaich, G. J.; Iacono, S. T. Chem. Commun. 2016, 52, 5242-5245. doi:10.1039/c6cc00897f

236. Lee, K. Y.; Mooney, D. J. Chem. Rev. 2001, 101, 1869-1880. doi:10.1021/cr000108x

237.llker, M. F.; Nüsslein, K.; Tew, G. N.; Coughlin, E. B. J. Am. Chem. Soc. 2004, 126, 15870-15875. doi:10.1021/ja045664d 238. Gabriel, G. J.; Maegerlein, J. A.; Nelson, C. F.; Dabkowski, J. M.; Eren, T.; Nüsslein, K.; Tew, G. N. Chem. - Eur. J. 2009, 15, 433-439. doi:10.1002/chem.200801233

\section{License and Terms}

This is an Open Access article under the terms of the Creative Commons Attribution License (http://creativecommons.org/licenses/by/4.0). Please note that the reuse, redistribution and reproduction in particular requires that the authors and source are credited.

The license is subject to the Beilstein Journal of Organic Chemistry terms and conditions:

(https://www.beilstein-journals.org/bjoc)

The definitive version of this article is the electronic one which can be found at: $\underline{\text { doi: } 10.3762 / \text { bjoc. } 15.209}$ 